\title{
UTMOST GOOD FAITH IN REINSURANCE: A TRADITION IN NEED OF ADJUSTMENT
}

\author{
STEVEN W. Thomas*
}

\section{INTRODUCTION}

The Big Business Company's new chemical manufacturing plant uses several toxic chemicals im its manufacturing process. Due to concerns about environmental liability, Big Business determines that it needs $\$ 95$ million of liability insurance in excess of its $\$ 5$ million self-insured retention (SIR). ABC Insurance Company agrees to accept part of the risk. As is the practice im the insurance industry, this coverage will be layered. For the first layer of coverage that will be paid out if there is a loss $\mathrm{m}$ excess of Big Business's $\$ 5$ million SIR, in this case $\$ 5$ million, Big Business must pay a premium of $\$ 750,000$. The next $\$ 15$ inillion (the second layer) will be sold for a proportionately lower preiniuin of $\$ 850,000$, because it will only be tapped if the loss exceeds the $\$ 5$ million first layer of coverage. The third layer, $\$ 25$ million, will be sold for a premium of $\$ 200,000$, and finally, the last layer of $\$ 50$ million will be sold to Big Business for a premium of $\$ 250,000$.

$A B C$ agrees to cover only the first layer of $\$ 5$ million. $A B C$, howw ever, does not want to jeopardize its financial condition by insuring such a large, single risk. ABC thus cedes a portion of the risk to XYZ Reinsurance Company. $\mathrm{XYZ}$ agrees to reinsure $\mathrm{ABC}$ for $\$ 4$ inillion, or eighty percent of the risk. Even if Big Business sustains a large loss, $A B C$ will only lose its twenty percent share, with the remaining eighty percent being paid by its reinsurer, XYZ.

The agreement between $\mathrm{ABC}$ and $\mathrm{XYZ}$ illustrates a coininon relationship in the reinsurance market. Reinsurance is the ceding by one msurer (the "ceding imsurer" or "reinsured," in this case, ABC) ${ }^{1}$ of all or a portion of the risk it underwrites, pursuant to a policy or group of policies, to another insurer (the "reinsurer," in this case, XYZ). ${ }^{2}$ The

* This Note is dedicated to my father and mother, who made college and law school possible.

1. See Mark R. Greene, Risk and Insurance 175 (3d ed. 1973).

2. See 13A John A. Appleman \& Jean Appleman, Insurance Law and Practice $\S 7681$, at 480 (1976); see also Colonial Am. Life Ins. Co. v. Comm'r, 491 U.S. 244 (1989); 19 George J. Couch, Cyclopedia of Insurance LAW § 80:1, at 624 (2d ed. 1983). 
reinsurer agrees to indemnify the ceding insurer in return for a portion of the premium on the risk transferred. ${ }^{3}$

\section{A. The Purpose of Reinsurance}

The primary purpose of reinsurance is "to spread the risk of loss."4 First, it spreads the risk of catastrophic loss, ${ }^{5}$ which might bankrupt the ceding insurer. Second, reinsurance enables an original insurer to accept risks that would otherwise be beyond its capacity by allowing it to transfer a portion of that risk to reinsurers.

"[R]einsurance also serves a variety of subsidiary functions that are indispensable to the life of an insurance company."6 Remsurance frees capital reserves by permitting the ceding insurer to treat reinsurance as an asset on its financial stateinents ${ }^{7}$ and thus to reduce its legal reserve requireinent. ${ }^{8}$ The ceding insurer then possesses more capital to imvest or to use to insure inore and different types of risks. This system encourages smaller original msurers to coinpete with larger underwriters. ${ }^{9}$ Specifically, "reinsurance allows the ceding [insurer] to offer a more varied insurance market, thus enabling the ceder to accept a greater variety of risks and offer higher policy limits on the risks it accepts." 10 Thus, "[i]nsurance companies depend upon reinsurance contracts for financial

3. See Transcontinental Underwriters Agency v. American Agency Underwriters, 680 F.2d 298, 299 n.2 (3d Cir. 1982); Delta Holdings, Inc. v. National Distillers \& Chem. Corp., [1990 Transfer Binder] Fed. Sec. L. Rep. (CCH) || 95,227 (S.D.N.Y. Apr. 11, 1990); APPLEMAN \& APPLEMAN, supra note $2, \S 7681$, at 480 .

4. Bart C. Sullivan, Reinsurance in the Age of Crisis, 38 FED'N INs. \& CoRP. Couns. Q. 3, 4 (1987); see, e.g. , Excess \& Casualty Reins. Ass'n v. Insurance Coinin'r of Cal., 656 F.2d 491, 492 (9th Cir. 1981); American Reins. Co. v. Insurance Comm'n of Cal., 527 F. Supp. 444, 452 (C.D. Cal. 1981), affd, 696 F.2d 1267 (9th Cir. 1983).

5. See, e.g., Fontenot v. Marquette Casualty Co., 247 So. 2d 572, 576 (La. 1971).

6. Sullivan, supra note 4, at 4; see N. David Thoinpson, Critical Issues of the Eighties: How Trends in Reinsurance Will Affect Legal, Legislative, and Regulatory Actions, 16 Forum 1038, 1040 (1981).

7. See American Reinsurance, 527 F. Supp. at $452-53$ (discussing CAL. INs. CoDE $\$ \$ 922.1$ and 922.15, which allow treatment of reinsurance as asset on financial statements); Skandia Am. Reins. Corp. v. Schenck, 441 F. Supp. 715, 724 (S.D.N.Y. 1977) ("The prinary significance of reinsurance is that the insurer may treat it as an asset on its financial statements.").

8. "An insurance reserve is an allocation of financial resources for claims likely to be paid in the future. When a reserve is set, a hability is incurred which is reflected in the company's financial statements. Insurance companies are required to set reserves by both insurance regulations and accounting procedures." Unigard Sec. Ins. Co. v. North River Ins. Co., 762 F. Supp. 566, 580 (S.D.N.Y. 1991); see also Christiania Gen. Ins. Corp. v. Great Am. Ins. Co., No. 91-7912, slip op. 6809, 6819 (2d Cir. Sept. 3, 1992) ("Reserves reflect the insurer's estimation of expected losses and appear as liabilities on its financial statements.").

9. See Fontenot, 247 So. $2 \mathrm{~d}$ at 575-76.

10. Sullivan, supra note 4 , at 5 n.7. 
stability and hence for their ability to fulfill their obligations under their policies."11

\section{B. Types of Reinsurance}

Reinsurance is of two general types-facultative or treaty.12 Facultative reinsurance involves a ceding insurer purchasing reinsurance for a part, or all, of a single insurance policy it has written. ${ }^{13}$ Each reinsured policy requires separate negotiations. As the word "facultative" connotes, "botli the [ceding] insurer and the reinsurer have the individual faculty or option of accepting or rejecting each and every individual submission." 14 ABC and $\mathrm{XYZ}$, our liypothetical insurer and reinsurer, have entered into a facultative reinsurance agreement.

Treaty reinsurance, on the other hand, "covers specified classes of a ceding [insurer's] policies." 15 The treaty is a inaster agreennent that regulates a contmuing relationship between a reinsurer and its ceding insurer. ${ }^{16} \mathrm{~A}$ treaty is obligatory in nature in that it creates an obligation for the reinsurer: A reinsurer under a treaty may not decline to reinsure any classes of insurance that fall within the terms of the treaty. ${ }^{17}$ The ceding insurer thus selects the individual risks within the type covered by the treaty, settles or litigates individual clains, and manages the financial accounts.

Inagine, for example, that instead of entering into a facultative reinsurance agreeinent, ABC Insurance Company and XYZ Reinsurance Company had previously entered into a treaty reinsurance agreeinent whereunder XYZ would reinsure all of the general liability policies of the chemical manufacturimg class of business insured by $A B C$. When $A B C$ thereafter decides to insure Big Business Company's new chemical inanufacturing plant, $\mathrm{XYZ}$ is already contractually bound to reinsure a specified portion of the risk.

In sum, treaty reinsurance eitler covers a type of risk, insured by the ceding insurer, over a period of time-all railroad insurance, for example-or it covers losses incurred on all policies issued by the ceding

11. Corcoran v. Universal Reins. Corp., 713 F. Supp. 77, 82 (S.D.N.Y. 1989); see also Janet P. Moore, Reinsurance-Sharing the Risk, BRIEF: A.B.A. TORT INS. PRAC. SEC., May 1980, at 15, 15; Thompson, supra note 6, at 1040 .

12. See generally 1 Klaus Gerathewohl, Reinsurance Principles and Practice 64128 (1980) (discussing various types of reinsurance coverage).

13. See KenNeth R. Thompson, Reinsurance 55 (4th ed. 1966).

14. Thompson, supra note 6 , at 1039.

15. Donald W. Rees et al., Reinsurance Issues, in BAD FAITH LITIGATION AND INSURER v. INSURER DISPUTES 381, 397 (1988).

16. John S. Butler \& Robert M. MERkin, Reinsurance LAw § A.1.1-01 (1987).

17. $I d$. 
insurer to a particular insured. Facultative reinsurance, however, only reinsures a particular policy-an insurance policy on a manufacturing plant, for instance.

\section{Utmost Good Faith in Reinsurance}

Historically, the very nature of reinsurance mandated that the parties' contractual relations be based on uberrima fides, or "utmost good faitll." 18 This standard lias been applied not only to reinsurance, but to original imsurance as well. ${ }^{19}$ Black's Law Dictionary defines uberrima fides as "[ $[$ ]le most abundant good faith; absolute and perfect candor or openness and lionesty; the absence of any concealment or deception, lowever sliglit." 20 Utmost good faitlı contracts liave been described as "so delicate in character and so susceptible of abuse that unusual precautions must be observed by botl parties in their implementation."21 Cominentators liave thus noted that "the existence of this duty means that the parties to a reinsurance agreement will not be subject to the maxim of caveat emptor or 'let the buyer beware." "22

The duty of good faith exists with respect to any action necessary or desirable to place and maintain botlı parties within a fair and equitable agreement. ${ }^{23}$ Thus in applying a notion of utmost good faitli to the reinsurance contract, a court or an arbitrator will look to those aspects of the parties' relationship that demand suclı a duty. Utmost good faitlı traditionally lias meant that the reinsurer and the ceding insurer would conduct themselves in a manner of trust and full disclosure that led to long relationships. Indeed, it has been stated that "[i]f reinsurance were done entirely at arin's length, ... the substantial transactions that characterize reinsurance would effectively destroy its utility as we know it today." 24

As a result of this "utmost good faitll" tradition, few instances of litigated disputes arose during the early existence of an active reinsurance

18. See Thompson, supra note 13, at 90 (" 'Good faith' is the backbone of the whole system.").

19. See, e.g., Sun Mut. Ins. Co. v. Ocean Ins. Co., 107 U.S. 485, 510 (1883); Unigard Sec. Ins. Co. v. North River Ins. Co., 762 F. Supp. 566, 588 (S.D.N.Y. 1991).

20. BlaCK's Law Dictionary 1520 (6th ed. 1990).

21. Henry T. Kramer, The Nature of Reinsurance, in ReINSURANCE 1, 9 (Robert W. Strain ed., 1980).

22. T. Richard Kennedy, Good Faith Principles Judicially Imposed in Dealings Between Primary and Excess Insurers and Reinsurers, 26 TORT \& INS. L.J. 590, 597 (1991).

23. See Kramer, supra note 21 , at 9.

24. Id. 
market. ${ }^{25}$ Moreover, because most modern reinsurance contracts contain arbitration clauses, this trend has continued and only a sinall percentage of disagreements actually reach court. ${ }^{26}$ The scarcity of hitigated disputes led the New York Court of Appeals recently to state: "This appeal calls upon us to resolve a question of reinsurance law-a field in which differences have often been settled by handshakes and umpires, and pertinent precedents of this court are few in number."27

In recent years, economic conditions and legal developınents, particularly in the United States, have tested the depth and boundaries of uberrima fides in the reinsurance relationship. ${ }^{28}$ Additionally, probleıns with reinsurance arbitrations have resulted in more lawsuits. ${ }^{29}$ Some commentators even question the continued vitality of utmost good faith, ${ }^{30}$ and argue that the market is now one of caveat emptor, or "let the buyer beware."31 More specifically, because of this change in the reinsurance market, the incentives that once existed for parties to a reinsurance contract to act $m$ utınost good faith have deteriorated. The reinsurance market today does not have the saine profitable long term relationships that outweigh any single loss, repeat transactions, or dependence on reputation. As a result, whereas utınost good faith once proinoted an efficient reinsurance market by allowing the reinsurer to rely on the ceding insurer's disclosure without monitoring, these sophisticated parties inust now bargain for adequate protection. Where this bargaining has not occurred (often because the reinsurance contract at issue was drafted before the changes in the market), courts should fill in ambiguous contract

25. Michael J. Pugh et al., Recent Developments in Treaty Reinsurance, 11 INT'L Bus. LAw. 138,138 (1983).

26. Jonathan F. Bank \& Karen L. Bizzini, "Fraud" in the Context of Reinsurance, 40 FED'N INS. \& Corp. Couns. Q. 119, 119 (1990); see also Michael M. Marick et al., Excess, Surplus Lines and Reinsurance: Recent Developments, 26 TORT \& INS. L.J. 231, 231 (1991):

[A]rbitration clauses in reinsurance contracts have provided an efficient and effective nueans of resolving commercial disputes between the parties in an off-the-record, private setting where the parties ean subnit their cases to a panel of experts who render an inforinal decision according to their understanding of reinsurance custom and practice.

27. Sumitono Marine \& Fire Ius. Co. v. Cologne Reins. Co. of Am., 552 N.E.2d 139 (N.Y. 1990).

28. Eugene Jericho, Insurance and Reinsurance Disputes, 55 DeF. CouNs. J. 289, 289 (1988).

29. Marick et al., supra note 26, at 232; see also Robert Coulson, Reinsurance Arbitration: It's Time for a Tune-Up, 46 ARBITRATION, Sept. 1991, at 39.

30. See Jericho, supra note 28 , at 289 ("In many instances the old concept of utnost good faith between the parties has deteriorated.").

31. See John Milligan-Whyle \& Mary Cannon Veed, Bermudian, English and American Reinsurance Arbitration Law and Practice and Alternative Dispute Resolution Methods, 25 TORT \& INS. L.J. 120, 124 (1989) ("There are those who think today that caveat emptor should be or is the ethos of reinsurance."). 
terms with the terms the parties would have contracted for ex ante. ${ }^{32}$ This Note advocates that courts adopt information forcing rules to give incentives to the ceding insurer to disclose fully and promptly, just as the market's requirement of utmost good faith once did.

This Note also advocates a departure from the mistaken notion that rules that govern the construction of original insurance should apply equally to reinsurance. ${ }^{33}$ The business and contractual relationships between a reinsurer and its ceding insurer differ substantially from those found in original insurance. First, reinsurance involves two sophisticated business entities who bargain at arm's length for the terms of the contract. Original insurance, in contrast, is most often a contract of adhesion. Even where original insurance is sought by a sophisticated business, the situation still differs from that of a ceding insurer, who is necessarily familiar with the business of insurance. Second, a reinsurance contract is one of indemnity, not of liability as are original insurance contracts. Moreover, facultative and treaty reinsurance contracts involve different considerations because of the obligatory nature of treaty reinsurance. Finally, a reinsurer, unlike an original insurer, does not investigate the risk, and typically does not participate in the investigation of claims. Rather, a reinsurer relies on the investigation of its ceding insurer.

Because of these differences between original insurance and reinsurance, this Note also advocates that courts and arbitrators dispel the myth of utmost good faith. Although the business relationship between the reinsurer and its ceding insurer described above does contain some elements that are similar to those in original insurance that lead to a need for utmost good faith, the differences between original insurance and reinsurance argue for a more fact-specific application of the good faith standard. Two factors support the cliaracterization of reinsurance contracts as contracts of utmost good faitli: first, a factor similar to those factors in original insurance that led to the characterization of original insurance contracts as contracts of utmost good faith-the knowledge of the risk is in the liands of one of the parties, in this case the ceding insurer; and second, a factor not present in original insurance-the reinsurer does not investigate a claim, but rather relies on the ceding msurer's investigation of the original insured. Nevertheless, a blanket characterization of all reinsurance contracts as contracts of utmost good

32. Lucian A. Bebchuk, Limiting Contractual Freedom in Corporate Law: The Desirable Constraints on Charter Amendments, 102 HARV. L. REV. 1820, 1827 (1989).

33. See, e.g., Fortress Re, Inc. v. Jefferson Ins. Co. of N.Y., 465 F. Supp. 333, 338 (E.D.N.C. 1978) (citing APPLEMAN \& APPLEMAN, supra note 2, § 7686, at 500), aff d, 628 F.2d 860 (4th Cir. 1980). 
faith would be too hasty. There is an important difference between reinsurance and original insurance that argues against such a characterization: Reinsurance involves two sophisticated business entities familiar with the business of insurance who bargain at arm's length for the terms in their contract.

In reality, there is ouly one standard of good faith. This standard, however, may be interpreted differently in light of the circunnstances peculiar to the relationship of the parties. As the Second Restatement of Contracts explains: "The phrase 'good faith' is used in a variety of contexts, and its meaning varies somewhat with the context." 34 No hardline rule should or could be apphed to reinsurance generally. Rather, the circumstances of each case must be examined to determine whether the standard of good faith is met.

Part I of this Note examines the role of utmost good faith in the reinsurance inarket. Part I(A) discusses the historic nature of the role of utmost good faith im reinsurance and the reasons given to characterize and enforce an utmost good faith duty in the inodern market. Part I(B) surveys the modern developinents that are eroding the concept of utinost good faith in the reinsurance relationship. As incentives for modern reinsurers and ceding insurers to adhere to the traditional "honorable" aspects of their relationships deteriorate, the arguinents for courts and arbitrators to interpret reinsurance contracts as contracts of utmost good faith are significantly weakened. Part $\mathrm{I}(\mathrm{C})$ employs an econounic analysis to explain utınost good faith's historical importance to an effecient reinsurance market because it proinoted proinpt and full disclosure by the ceding insurer to its reinsurer. The Part argues, however, that as the market has changed, parties should bargain for the proper protection. Where that has not occurred, courts should fill in ambiguous contract ternis with infornation forcing legal rules that furnish incentives for the ceding insurer to provide proinpt and full information to its reinsurer.

After surveying the development of the utmost good faith tradition in reinsurance and setting forth the arguments for and against the continuation of this tradition, Parts II and III discuss two stages in the reinsurance relationship in which good faith duties arise. Part II examines the existing law pertaining to disclosure at the inception of the contract. Part III considers notice requirements of the ceding insurer to the reinsurer. Whereas courts have differed on what role, if any, the duty of good faith should play regarding notice, this Note argues for a three-part test that includes a good faith prong. Suggestions for the proper standard of good faith in reinsurance and its specific application by courts

34. RESTATEMENT (SECOND) OF CONTRACTS § 205 (1981). 
and arbitrators to disclosure and notice duties follow each section. Permeating these discussions is the idea that because reinsurance differs from original imsurance, the rationales that support a rule of construction, interpretation, or pohicy in original insurance may not support a similar rule in reinsurance.

\section{UTMOST GOOD FAITH}

Although it can be understood as a description of the manner of dealing between the ceding insurer and its reinsurer, utmost good faith has legal implications as well. The duty of utmost good faith "is implied in contracts of reinsurance, and is im addition to the duties expressly imposed by the agreement." 35 The development of utmost good faith im reinsurance is understandable in the historical context; lowever, the argument that the tradition of utmost good faith is im itself a reason for contimued adherence to the standard by courts and commentators is unconvincing.

\section{A. The Historical Development of Utmost Good Faith and Arguments for and Against Adherence to the Tradition}

The historical development of reinsurance from ocean marine insurance, the metlods used in writing reinsurance contracts, and the international nature of the busmess are offered by commentators and courts as reasons for adherence to the utmost good faith standard. Althougli these characteristics help to explain why this standard developed, they do not furnish independent reasons for a duty of utmost good faith. The fact that the information concerning the risk lies with the ceding insurer, however, must be carefully considered.

First, the historical conditions from which reinsurance derived established a tradition of uberrima fides. Reinsurance originated in the field of ocean marine insurance. ${ }^{36}$ The practical necessities of insuring cargo or slips that were often at distant ports required a certam degree of trust and good faitli between the parties. ${ }^{37}$

Altliough the development of the utmost good faitli standard out of ocean inarine insurance may by implication apply to marine reinsurance, it does not seein relevant to otlier lines of reinsurance. Indeed, with the

35. Marick et al., supra note 26 , at 233.

36. 2 GerATHEwOHL, supra note 12, at 653. "The first agreement that can truly be called a reinsurance treaty was effeeted in Genoa on July 12, $1370 \ldots$. . Id. at 649.

37. See Stecker v. American Home Fire Assur. Co., 84 N.E.2d 797, 799 (N.Y. 1949) ("The reasons which brought into being the strict marine insurance law doctrine as to disclosures, go far back into the early days of marine insurance, when sailing ships in faraway seas were insured in London by underwriters who could get no information except from the shipowners."). 
improved communications of the modern world, there is hittle reason for even the distance across an ocean to prevent knowledge of the risk.

Second, the methods used in writing insurance, particularly at Lloyd's of London, contributed to the need for utmost good faith. ${ }^{38}$ At Lloyd's, the degree of trust the parties placed in each other was reflected through the casual process by which reinsurance contracts were formed. If a reinsurer agreed to cover the risks of the ceding insurer, he merely initialed a "ship," thus creating a binding agreement. ${ }^{39}$

Although Lloyd's certainly was, and still is, an important market for reinsurance, modern reinsurance contracts are written doinestically and abroad-in markets other than Lloyd's. The methods of Lloyd's alone thus cannot support a uinversal rule of utmost good faith.

Third, some argue that the conditions that historically led to the developinent of the utmost good faith tradition still persist in the reinsurance market and continue to deinand adherence to the utmost good faith doctrine. Reinsurance has continued to develop in an international market, ${ }^{40}$ and today "is, of necessity, a highly international business." 41 The constraints of capital necessitate this type of inarket: "There is not enough capital or capacity in any one country to let the theory of the law of large numbers operate effectively without utilizing the world reinsurance inarkets." 42 As a consequence of the international nature of reinsurance, "reinsurance custoins . . . have certain uniform characteristics to be found worldwide." 43 Moreover, the international nature of the reinsurance market often means that not only does a ceding insurer alone

38. The gathering of "sober, respectable businessmen" in London taverns in the 1600 s "for the business of underwriting," C.E. GoldING \& D. KING-PAGE, LLOYD'S 4 (1952), established the traditional basis for interactions withm the reinsurance marketplace: Reinsurance was established as an honorable agreeinent. John L. Baringer, The Reinsurance Market: The Assuming Reinsurer, in RE1NSURANCE, supra note 21 , at $329,343$.

39. "In the London market-the Mecca of the reinsurance world-this was traditionally accomplished by the ceding company or its broker preparing a slip with brief details of the risk to be placed; the ship was then taken to prospective reinsurers . . . ." Sumitoino Marine \& Fire Ins. Co. v. Cologne Reins. Co., 552 N.E.2d 139, 142 (N.Y. 1990).

40. 2 GeRATHEwOHL, supra note 12 , at 674 . Gerathewohl writes that:

By comparing the insurance laws of the 17 th and 18 th centuries and considering that ocean trade at the time already encompassed the whole of Europe and other continents, one realizes that the acts and legal provisions introduced in individual countries did not by any means constitute new law, but rather merely sought to establish, by way of legal declaraId. tions, the existing system of international custoinary law.

41. Thompson, supra note 6, at 1045; see also Jannette Pinnock, A Review of Six Clauses Commonly Found in Reinsurance Contracts, 133 SolIC. J. 1562, 1562 (1989) ("Reinsurance is international in nature ....").

42. Thompson, supra note 6 , at 1045 .

43. 1 GERATHEWOHL, supra note 12, at 460; see also Bank \& Bizzini, supra note 26, at 124 ("Courts also recognize the importance of applying the custom and practice in the reinsurance industry to the dispute at hand."). 
possess the knowledge of the risk, but that a reinsurer atteinpting to duplicate its ceding insurer's investigation would be forced to do so on another continent. Many courts and commentators have therefore attested that one of the cardinal principles of reinsurance in the international setting is that obligations of parties to a reinsurance contract are ones of utmost good faith. ${ }^{44}$

One inight argue that because the rule of utinost good faith is universally applied, unilateral deviations from this standard by U.S. courts and arbitrators could larm the U.S. insurance business. Nevertheless, the international nature of the reinsurance business today still does not furnish an independent reason for the apphication of a rule of utinost good faith. As Part I(B) deinonstrates, reinsurers and ceding insurers are already disregarding the tradition of utmost good faitl as the business becoines less profitable and more coinpetitive.

Finally, the last arguinent does provide an independent reason for enforcing a duty of utmost good faitl between the parties to a reinsurance contract: The knowledge of the risk, both in the disclosure of inaterial information used to set the premium, and in the actual administration of the contract, lies witl the ceding insurer. ${ }^{45}$ It is the ceding nisurer who investigates risks and claims; normally, the reinsurer will have no contact with the original insured. Thus, numerous important business transactions conducted by the ceding insurer are largely beyond the influence of the reinsurer. ${ }^{46}$

Klaus Gerathewohl, the leading writer in the reinsurance area, stated that "renisurance customs have developed out of the methods and needs of reinsurance and-due to the very nature of renisurance relations-depend to a particular extent on the principle of . . uberrima fides."47 The absence of utınost good faitlı within the reinsurance inarket

44. See Security Mut. Casualty Co. v. Affiliated FM Ins. Co., 471 F.2d 238, 246 (8th Cir. 1972); Bank and Bizzini, supra note 26, at 124; Jericho, supra note 28, at 296 (noting tluat good faith and fair dealing "carried the reinsurance industry for so many decades"); Milligan-Whyle \& Veed, supra note 31, at 124 ("Reinsurance has traditionally been said to operate on the reciprocal duty of utmost good faith."); Donald W. Rees \& Carol E. Reese, Reinsurance: The Basics and Bad Faith Considerations, 39 FED'N INS. \& CoRP. Couns. Q. 323, 326 (1989) ("Contracts of reinsurance are of 'utmost good faith.' ") (citing Security Mutual, 471 F.2d at 246); Thoinpson, supra note 6, at 1042 ("Reinsurance agreements are inade for the mutual benefit of the two companies and are not only considered gentleinen's agreeinents, but contracts of utmost good faith as well.").

45. Baringer, supra note 38 , at 343 ("The initial information on which the reinsurer bases its judgment, either for rateinaking purposes or for purposes of determining reinsurance coinmission rates to be paid on pro rata treaty accounts, is supplied by the reinsured and accepted by the reinsurer in good faith.").

46. 1 GERATHEwOHL, supra note 12 , at 413 .

47. Id. at 460; see also Baringer, supra note 38, at 343 ("Reinsurance is considered an honorable engageinent between two soplisticated parties, primarily because the transactions by their nature must be based upon trust and confidence between the reinsured and the reinsurer."). 
could spawn increased costs as reinsurers are forced either to hire their own investigative teams to verify and thus to duplicate the assessinent of the risk by the ceding insurers, or to increase premiums to cover the greater risk. ${ }^{48}$ Reinsurers and ceding insurers liave depended on the principle of utmost good faitl to clieck the abuse inherent in this relationship and to prevent wasted duplication of effort that would result in higher premiums. ${ }^{49}$ Commentators have noted not ouly that "[u]tmost good faitl is vital in any reinsurance relationship,"so but also that "[w]ithout this bond of trust between the parties, the industry could not function." 51

As Part I(B) describes, however, changes in the reinsurance market lave decreased incentives for ceding insurers to adhere to the standard of utmost good faith. Nonetheless, this does not spell doom for the market because a reinsurance contract is a bargam between two soplisticated parties who can contract for the necessary protection. Where this prior agreement has not occurred and the contract is ambiguous, courts should apply a flexible standard of "good faith" that, because of the structure of the reinsurance relationship and the consequent need for prompt and full disclosure for an efficient market, formulates rules that create incentives for such disclosure.

\section{B. Changes in the Reinsurance Market That Have Eroded Utmost Good Faith in the Reinsurance Relationship}

In an earlier era, perhaps it inade sense to generalize and find a duty of utinost good faith inherent in the reinsurance relationship. Today, lowever, that relationship has changed: The "reinsurance relationship" between a reinsurer and its ceding insurer is conducted along a broad

48. See Kramer, supra note 21 , at 11 .

49. Barry R. Ostrager \& Thomas R. Newman, Handbook on Insurance Coverage DisputEs $\S 14.01$, at 459 (4th ed. 1991) (discussing purpose of "follow the fortunes" clause to "preclude wasteful relitigation by a reinsurer of defenses to underlying policy coverage in cases where the ceding insurer has in good faith paid a settlement or judgment"). Some commentators argue that longstanding treaty relationships that were profitable to both parties could be damaged by deviations from the good faith standard. See Robert M. Mangino \& Anne M. Flynn, The Reaction from Abroad: How Foreign Reinsurers View Litigation in the U.S., BRIEF: A.B.A. TORT INS. PRAC. SEC., Fall 1988, at 24, 28-29; see also Thompson, supra note 6, at 1042 ("Reinsurance agreements are made for the mutual benefit of the two companies and are ... contracts of utınost good faith."). As Gerathewohl summarized: "The reinsurer ... must rely on his treaty partner and be sure he will carry at least approximately the retention stipulated, select and rate the risks ceded with due care, settle losses according to dihigent business practices, and make up aceounts properly and in line with accepted accounting procedures." 1 GERATHEWOHL, supra note 12, at 413.

50. Thompson, supra note 6, at 1042; see also WILLIAM J. LANGLER, THE BUSINESS Of REINSURANCE ix (1st ed. 1954) (noting that "[r]einsurance is distinctly to be regarded as an honorable engagement").

51. Baringer, supra note 38 , at 343. 
continuuin of trust and mistrust. The actions that must be taken to conform to a duty of good faith depend on the circumstances of the particular relationship and cannot be generalized to all reinsurance relationships.

During the past decade, the increase in tensions and in resultant disputes between reinsurers and ceding insurers has resulted in a deterioration in the practice of utinost good faith, and has demonstrated that the reinsurance inarket no longer depends upon and cannot expect adherence to this standard. These tensions and disputes have arisen froin a multitude of causes, most of which relate directly to profitability. ${ }^{52}$ Thus although reinsurance has traditionally operated on the duty of utinost good faith, that "tradition worked more uneventfully when reinsurance was inarvelously profitable."53 Formerly, when there was economic imcentive for reinsurers to hold down costs by "trusting" the faith of the ceding insurer in its assessment of risks and processing and settleinent of claims, ${ }^{54}$ neither party would risk severing long, profitable relationships over minor grievances. Today, however, profits have decreased, and dainage awards, particularly for environmental hability, have far exceeded any loss bargained or planned for; as a result, tensions between ceding insurers and reinsurers have increased. Whereas formerly no single loss was considered inore important than the longstanding relationship, today a single environmental loss may exceed all expected profits.

Other factors related to profitability have also infiuenced the remsurance inarket. Reinsurers "sought increased cash flow froin premiums to produce investinent incoine opportumities when interest rates were high without carefully examining their own capabilities for the class of business being undertaken." 55 Ceding insurers decreased their risk to little or no exposure by remsuring heavily or, in some cases, fully. ${ }^{56}$ Further, because of underwriting losses (risks where payinent exceeded the receipt of preimums) and slimmer profit inargins, ceding insurers started shopping for the best rates possible at the end of every treaty reinsurance contract or period ${ }^{57}$-if better rates were offered by a new reinsurer, then longstanding relationships would abruptly terminate. ${ }^{58}$

One cominentator has suggested tliat tlie crux of the problein can more accurately be described as "tlie fundainental failure by domestic
52. Jericho, supra note 28, at 289.
53. Milligan-Whyle \& Veed, supra note 31 , at 124.
54. See Kramer, supra note 21 , at 9.
55. Jericho, supra note 28 , at 289.
56. Id.
57. Mangino \& Flynn, supra note 49, at 29.
58. Id. 
insurers to coinprehend that the American insurance experience is not a primary end in itself, but is instead a cog (albeit a critical one) in the worldwide market for insurance and reinsurance."59 To illustrate, consider the role of skyrocketing legal awards against insurers in the United States, particularly for extra-contractual and pumitive damages, in the erosion of the duty of utmost good faith:

[I]nternational reinsurers perceive the considerations used to justify those departures froin contract language as peculiar to the relationship between insurers and pohicyholders in America and wholly inapplicable to the insurer-reinsurer relationship. This is particularly true with respect to the international reinsurers for whoin the concept of uberides fides, or "utmost good faith," on the part of the ceding [insurer] to the "gentlemanly European reinsurer" has been an essential aspect of the reinsurance relationship. 60

In light of this point, it is not surprising that foreign reinsurers have refused to contribute to punitive damage awards agamst the ceding insurer for acting in bad faith. ${ }^{61}$ Some foreign reinsurers have even withdrawn from the U.S. inarket. 62

These probleins are augmented by insolvent or nearly insolvent original insurers, inflation, and perliaps inost importantly, environmental claims that tap reinsurance policies that were written thirty to forty years ago and were not designed to deal with conteinporary concepts of hability. ${ }^{63}$ The environmental liability (nost often occupational or site cleanup losses) for a single risk can be in the hundreds of millions of dollars and can affect pohicies written over a number of years, even decades. These losses tap reinsurance policies at a level never anticipated. Because of the sheer quantities of inoney involved, the interpretation of policies and of ceding insurers' and reinsurers' duties can affect the very survival of an insurance coinpany.

In this setting, serious disputes have arisen and the traditional relationships of trust and confidence have diminished, especially ainong the new and inexperienced insurers seeking to enter fields of risk-taking in which they are not properly staffed, experienced, or adequately financed. ${ }^{64}$ As a result, "old relationships of trust and compromise" have

\footnotetext{
59. Sullivan, supra note 4 , at 28 .

60. Mangino \& Flynn, supra note 49 , at 27.

61. Sullivan, supra note 4 , at 13-16.

62. Id. at 15 .

63. Jim Teff, Alarm from London, BRIEF: A.B.A. ToRT INS. Prac. SEC., Fall 1985, at 16, 19.

64. Jericho, supra note 28 , at 289.
} 
broken down. ${ }^{65}$ In sum, the millions of dollars that are at stake have hardened what was once a rather loose and informal relationship.

In the reinsurance relationship, the conduct of utmost good faith has dechined. As the remsurers and ceding insurers depart from the customs and traditions of trust, they demonstrate that remsurance contracts are not contracts of utmost good faith, but rather contracts between two sophisticated business entities capable of contracting to protect their own interests. The enforcement of contracts formed in this changing setting should not reflect a rigid rule of utmost good faith. Whatever the circumstances of the contract formation, good faith remains a flexible standard that courts and arbitrators can apply to parties' specific situations. This Note seeks only to establish that the circumstances that perhaps once supported a blanket characterization of reinsurance contracts as contracts of utmost good faith have changed.

\section{An Economic Justification}

The above reasons for the development of utinost good faith, and the arguments for and against continued adherence to this standard, may be more helpfully explained by an economic analysis. In the past, the reinsurance market has rehed on utinost good faith to decrease inoritoring costs and ex ante contracting costs. The market determined that it was more efficient for the ceding insurer to investigate the risk or claim and for the remsurer to rely on the ceding imsurer's disclosure of that information. Thus, rather than the parties atteinpting to contract for every contingency, or the remsurer einploying mointors to investigate risks, to review claims to the original insurer for the likelihood of the remsurer's involvement, and to investigate claims, the parties rehed on the duty of utinost good faith of the ceding insurer. Because the market enforced the utmost good faith duty, recourse to legal ineans was rare. The principals in the reinsurance inarket were relatively few and widely known, and repeat transactions were the norm. Thus reputation was an inportant component of future incoine. ${ }^{66}$ Where profitable long-ternn relationships existed, the loss of repeat business was a penalty that outweighed the short-term gains of misrepresentation. ${ }^{67}$ Therefore, selfinterest was inore important than legal norms in governing parties' actions.

65. Paul F. Butler, Jr. and Robert V. Potter, Jr., The Primary Carrier Caught in the Middle with Bad Faith Exposure to Its Insureds, Excess Carriers and Reinsurers, 24 TORT \& INS. L.J. 118, 132 (1988).

66. See Frank H. Easterbroox \& Daniel R. Fischel, The Economic Structure of CORPORATE LAW $95-96$ (1991).

67. Id. at 95. 
In recent years, with the many new entrants into the reinsurance market, a firm's reputation has become a less effective check on its behavior: The more firms in an industry, the more difficult it is for others to learn of one firm's reputation. In addition, as profitability has declined, long-term relationships have deteriorated, inaking repeat transactions less likely. Finally, large environmental losses that jeopardize the very existence of a ceding insurer or a reinsurer may make the gains of a misrepresentation outweigh any long-term benefits froin the relationship. As a result, market forces have become a less effective method of enforcing the prompt and full disclosure that reinsurance contracts, and the reinsurance relationship, require.

Accordingly, actions that the market may have deterred in eartier times are now becoming the subjects of court cases and arbitrations. In a changing market, the challenge to courts and arbitrators is to adopt legal rules that promote market efficiency. The remsurance inarket appears to be slow to impound new information into new contract formations, ${ }^{68}$ perhaps due to the strong traditions and the time (often years, and in some cases, decades) it takes a large claim to percolate through the many layers of reinsurance. Moreover, often the reinsurance contracts at issue were drafted many years before the new environmental risk was discovered and thus could not anticipate the future changes in the reinsurance market.

Parts II and III describe courts' attempts to apply a standard of good faith to reinsurance contracts at the inception of such contracts and to the notice of a claim. These Parts urge a modern approach that recognizes not only the changes in the reinsurance inarket, but also the fundamental differences between reinsurance and original insurance. This approach embodies two general rules: (1) Because the reinsurance contract reflects the arm's length negotiation of two sophisticated and experienced parties, courts should enforce their bargain; and (2) Where terms are ambiguous, courts should enforce rules that give incentives for prompt and full disclosure.

\section{DUTY OF Disclosure}

The rationale for the duty of utmost good faith perhaps is strongest when applied to the disclosure by the ceding insurer of the material facts pertaiming to the risk. As one court has stated: "Insurance authorities are agreed that a ceding company, which is . . . in possession of all the details relating to the risk, is required to exercise the utmost good faith in

68. See Steven P. Croley \& Jon D. Hanson, What Liability Crisis? An Alternative Explanation for Recent Events in Products Liability, 8 YALE J. ON REG. 1, 107-10 (1991). 
all its dealings with the reinsurer."69 The courts, lowever, have applied this duty differently in cases of concealment on the one liand, and cases of misrepresentation of material facts on the otler. Courts have also properly recognized the differences between facultative and treaty reinsurance and applied different standards of good faith to eacli.

\section{A. Concealment or Nondisclosure of Material Facts}

Inherent in the concept of "utmost good faith" is the duty of the ceding insurer to disclose all known information material to the risk. ${ }^{70}$ As one court has explained:

$[B]$ etween the reinsured and reinsurer, there is no principle of imputed knowledge of facts inaterial to the risk that the reinsurer is asked to assuine; to the contrary, there is a duty on the reinsured to disclose such facts. Indeed, were this not so, the business of reinsurance would rest on blind faith in the [ceding insurer]..$^{71}$

But courts have been imconsistent as to whether utmost good faith de- . mands that mere nondisclosure is sufficient for the rescission of the reinsurance contract. Consideration of the type and form of reinsurance at issue has played a key role im their reasoning.

1. Marine Reinsurance. The United States Supreme Court in Sun Mutual Insurance Company v. Ocean Insurance Company ${ }^{72}$ held that a ceding insurer's specific intent to conceal information from the reinsurer is not necessary to rescind the reinsurance contract; an innocent failure to disclose a material fact is sufficient. ${ }^{73}$ The Court mitially noted that "[i]n respect to the duty of disclosing all material facts, the case of remsurance does not differ from that of original insurance. The obligation in both cases is one of uberrimae fidei." ${ }^{\prime 4}$ However, the Court did go on to say that the duty of disclosing material facts "may be greater

69. Northwestern Mut. Fire Ass'n v. Union Mut. Fire Ins. Co. of Providence, 144 F.2d 274, 276 (9th Cir. 1944); see also Sun Mut. Ins. Co. v. Ocean Ins. Co., 107 U.S. 485, 510 (1883) (requiring disclosure of all naterial facts).

70. See General Reins. Corp. v. Southern Sur. Co., 27 F.2d 265, 271 (8th Cir. 1928); Kramer, supra note 21, at 9 ("A basic duty of the reinsured is to disclose to the reinsurer all known niformation touching on the risk of loss."); Reinsurance Coverage Panel Presentation, 64 TrTLE NEws 27, 30 (1986) (reinarks of Ray E. Sweat):

On what bases is reinsurance conducted? Well, full disclosure. It has to be all on good

faith and full disclosure basis [sic] so each company that is writing a policy, and ceding or transferring, to another company liability nakes full disclosure of all the problems that are involved in that particular transaction.

71. A/S Ivarans Rederei v. Puerto Rico Ports Auth., 617 F.2d 903, 905 (1st Cir. 1980) (citation oinitted).

72. 107 U.S. 485 (1883).

73. Id. at 510 .

74. Id. Although the Court's language was not limited and could inpliedly extend to all reinsurance situations, the case involved narine reinsurance and has generally been cited as such. 
in a case of reinsurance than as between the parties to an original insurance."75 The Court explained that in reinsurance,

the party seeking to shift the risk he has taken is bound to communicate his knowledge of the character of the original insured, where such information would be likely to influence the judgment of an underwriter; while in [the case of original imsurance], the party ... is "not bound, nor could it be expected that he should speak evil of himself."76

The Court quoted with approval the nineteenth-century insurance expert John Duer:

It is the duty of the assured to place the underwriter in the same situation as himself; to give to him the same means and opportunity of judging of the value of the risks; and when any circuinstance is withheld, however slight and immaterial it may have seemed to himself, that, if disclosed, would probably have influenced the terms of the insurance, the concealment vitiates the policy. ${ }^{77}$

Thus the Court endorsed rescission of the reinsurance contract where the concealment, though ninocent, could have influenced the terms of the policy. The concealed fact need not have been sufficient to cause the reinsurer to reject the risk altogether.

In $A / S$ Ivarans Rederei v. Puerto Rico Ports Authority, the court specifically lield that in the case of reinsurance "[w] hether the nondisclosure of a known fact inaterial to a marine risk was intended or not is beside the point; sucl nondisclosure voids the policy."78 The court clearly narrowed its lolding to marine reinsurance, for as another court explained: "The reasons which brought into being the strict inarine insurance law doctrine as to disclosures, go far back into the early days of inarine insurance, when sailing ships in faraway seas were insured in London by underwriters who could get no information except froin the shipowners."79 Commentators often cite $A / S$ Ivarans for the proposition that inarine reinsurance entails a greater and stricter duty to disclose. ${ }^{80} \mathrm{~A}$ clear rule exists tliat a inarine reinsurance contract inay be rescinded for innocent nondisclosure.

2. Non-Marine Reinsurance. Coinmentators disagree on whether the "weight of authority" holds that "mere nondisclosure" is sufficient to

75. Id.

76. Id. (quoting New York Bowery Fire Ins. Co. v. New York Fire Ins. Co., 17 Wend. 359, 367 (N.Y. Sup. Ct. 1837)).

77. Id. at 510-11 (quoting 2 John Duer, The LAW and Practice of Marine Insurance, Lect. 13, pt. 1, § 13, at 398 (New York, John S. Voorheis 1846)).

78. 617 F.2d 903, 905 (1st Cir. 1980) (emphasis added); see also Fireman's Fund Ins. Co. v. Wilburn Boat Co., 300 F.2d 631, 646 (5th Cir.), cert. denied, 370 U.S. 925 (1962).

79. Stecker v. American Home Fire Assur. Co., 84 N.E.2d 797, 799 (N.Y. 1949).

80. See, eg., Bank and Bizzini, supra note 26 , at 126. 
rescind a non-marine reinsurance contract, or whether intentional concealment is necessary. ${ }^{81}$ The disagreeinent often arises from a general failure to consider the different circumstances of the reinsurer-ceding insurer relationship as compared to that of an original insurer and its insured when applying the good faith standard. The majority rule in original insurance is that a good faith, unintentional nondisclosure does not void the policy. ${ }^{82}$ Courts and commentators continue to insist that "the rules which govern the construction of contracts and original pohcies of insurance are applicable [generally] to reinsurance contracts," notwithstanding the characterization of reinsurance as a separate class of insurance, ${ }^{84}$ and reinsurance contracts as contracts of indemnity rather than of hability. ${ }^{85}$ A reinsurer-ceding insurer relationship involves two sophisticated insurance companies dealing with a contract of indemnity in which one party depends on the other for information of the risk. Only when the very different circumstances of the reinsurance relationship are considered can a consistent and rational jurisprudence be estabhished. ${ }^{86}$

a. Intentional concealment required to void contract. The writers often cite two cases, General Reinsurance Corp. v. Southern Surety Co. of Des Moines ${ }^{87}$ and Old Reliable Fire Insurance Co. v. Castle Reinsurance $\mathrm{Co}^{88}$ for the proposition that "courts will not rescind the reinsurance contract for 'inere nondisclosure,' instead requiring intentional concealment of known, material facts or a wilful, or bad faith refusal to ascertain such facts." 89 General Reinsurance clearly supports this proposition. The court wrote that "we think that it was indispensable to a valid defense to show either intentional concealment of known

81. Compare Ostrager \& NewMan, supra note 49, § 14.03(a), at 474 ("To make the contract voidable, it is not necessary that the reinsured have a specific imtent to conceal information from the reinsurer; an innocent failure to disclose a material fact is sufficient.") with T. Richard Kennedy, Non-disclosure and Misrepresentation in Insurance Contracts in the USA, 14 INT'L BUS. LAW. 104, 105 (1986) (noting that "weight of authority in non-marine reinsurance cases" does not apply the inere disclosure rule, but rather requires that concealment be in bad faith with the intent to mislead).

82. Robert E. KeETON \& ALAN I. Widiss, INSURANCE LAW § 5.8, at 573 (student ed. 1988).

83. See, e.g., APPLEMAN \& APPLEMAN, supra note $2, \S 7686$, at 500 .

84. 19 CouCH, supra note $2, \S 80: 2$, at 624 .

85. APpleman \& APPLEMAN, supra note $2, \S 7686$, at 503.

86. See generally 1 GERATHEWOHL, supra note 12, at 402-12 (discussing provisions of German original insurance law not applicable to reinsurance, emphasizing laws passed exclusively to protect the insured).

87. 27 F.2d 265, 273 (8th Cir. 1928).

88. 665 F.2d 239, 244 (8th Cir. 1981).

89. Deborah F. Cohen \& Henry M. Justi, Reinsurance Issues, in INSURER vs. INSURER DISPUTES 1990, at 211, 222 (PLI Com. Law Practice Course Handbook Series No. 534, 1990); see also Rees \& Reese, supra note 44 , at 327. 
1naterial facts, or bad faith in refusing to ascertain such facts."90 The court reached this result by holding that the same principles of law regarding concealment govern both reinsurance and original insurance; ${ }^{91}$ and applying the saine standard of good faith to both: "The strictest good faith is required on the part of one seeking original insurance, and also on the part of one seeking reinsurance." 92

Although Old Reliable did not state its rule of intentional concealinent as plainly as General Reinsurance had, Old Reliable clearly did not require that the ceding insurer place the reinsurer im the sane position as itself. Moreover, it is uncertain, because of a third-party complaint asserted by the reinsurer against the broker, whether the court viewed the broker as the ceding insurer's agent and imputed its actions to the ceding insurer..$^{93}$ Old Reliable turned on the fact that the broker had provided his entire file to the underwriter (reinsurer), which included the disputed automobile physical dainage risk as property business. The court did not think that utinost good faith required the broker to specifically tell the reinsurer the exact annount of the automobile content in the treaty reinsurance contract. "By custoin and practice in the reinsurance industry, and in the London market in particular, the usual and customary practice of underwriters is to ask questions and seek additional information froin brokers when they have questions concerning potential business."94 Further, the court stated that the ceding insurer's (as represented by the broker) "actions do not ainount to fraudulent or negligent omissions." 95 It is not clear whether neghigent ormssions would include a bad faith refusal to ascertain facts as required in General Reinsurance, or inerely a careless ormission.

b. Innocent nondisclosure voids the reinsurance contract. The New York Court of Appcals, in Sumitomo Marine \& Fire Insurance

90. General Reinsurance, 27 F.2d at 273.

91. Id. at 271.

92. Id.

93. Old Reliable, 665 F.2d at 241.

94. Id. at 243 (quoting district court opinion, 507 F. Supp. 46,49 (E.D. Mo. 1981)). The reinsurer contested the implicit meaning of this statennent that the ceding insurer need not disclose all knowledge that it has that the ceding insurer believes might affect the risk. But see Morrison Assur. Co. v. North Am. Reins. Corp., 588 F. Supp. 1324, 1328 (N.D. Ala. 1984), aff'd, 760 F.2d 279 (11th Cir. 1985) (Because the parties "were both sophisticated, experienced insurance coinpanies, [and] dealt at arms length," the remsurer did not owe a duty to the ceding insurer "to reveal ... its own internal thoughts, plans, suspicions and legal opinion.").

95. Old Reliable, 665 F.2d at 244 (emphasis added). The court was responding to what the reinsurers pleaded in the case. Id. at 242 . The court never stated what standard is necessary to rescind the contract. Based on its interpretation of reinsurance custom, it held that the ceding insurer disclosed all material mformation. Id. at 244. 
Co. v. Cologne Reinsurance Co., ${ }^{96}$ stated the more general rule: "A [ceding insurer] is obliged to disclose to potential reinsurers all 'material facts' concerning the original risk, and failure to do so generally entitles the reinsurer to rescission of its contract." 97 A line of cases thus holds that mere nondisclosure of a material fact is grounds for rescission. ${ }^{98}$ The Sumitomo court qualified the rule by limiting the information required to be disclosed. The ceding insurer ordinarily has no obligation to disclose to the reinsurer the terms upon which original insurance has been granted when those terms are commonly used in policies of that nature, and are standard terms of which the reinsurer ouglit to be aware. However, the court explained, the ceding insurer's offering its insured extended coverage or an unusual term would be a material fact which, if not disclosed, would render the reinsurance contract avoidable..$^{99}$

Califorma has codified this "mere nondisclosure" rule. ${ }^{100}$ One commentator, citing Jolın Duer and New York Bowery Fire Insurance Co. v. New York Fire Insurance Co, explained the significance of the statute's wording:

Both the authorities cited make clear that the omission from the statute of any reference to intent is meaningful, because intent and accident are irrelevant to the duty to disclose and to the consequences of failing to do so. The court appeared ... to treat non-marine reinsurance on the same footing with marine reinsurance im respect of concealment. ${ }^{101}$

3. Conclusion. The "mere nondisclosure rule" in reinsurance differs from the majority rule in original insurance that a good faith, unintentional nondisclosure, even of a material fact will not void the

96. 552 N.E.2d 139 (N.Y. 1990).

97. Id. at 143 (citing Royal Indem. Co. v. Preferred Accident Ins. Co., 276 N.Y.S. 313 (App. Div. 1934), aff d, 198 N.E. 407 (N.Y. 1935)).

98. Hare \& Chase, Inc. v. Natioual Sur. Co., 49 F.2d 447, 454 (S.D.N.Y. 1931), affd, 60 F.2d 909 (2d Cir.), cert denied, 287 U.S. 662 (1932); Royal Indemnity, 276 N.Y.S. at 318; Nationwide Mut. Ins. Co. v. Marsh, 472 N.E.2d 1061, 1062 (Ohio 1984); see also Southern Sur. Co. v. Fidelity \& Casualty Co., 50 F.2d 16, 19 (8th Cir. 1931) (where reinsurer underwrote risk without a disclosure of facts material to the risk, it may rescind if it promptly returned the premium it had received); New York Bowery Fire Ins. Co. v. New York Fire Ins. Co., 17 Wend. 359, 366-67 (N.Y. Sup. Ct. 1837) (ceding insurer's failure to disclose to reinsurer bad character of the insured would void policy).

99. Sumitomo, 552 N.E.2d at 143 (citing BUTLER \& MERRIN, REINSURANCE LAW § A6.4-04 (1988) and R.L. CARTER, REINSURANCE 125-26 (1979)).

100. CAL. INS. CODE $§ 622$ (West 1972) ("Where an insurer obtains reinsurance, he must cominunicate all the representations of the original insured, and also all the knowledge and information he possesses, whether previously or subsequently acquired, which are material to the risk.").

101. Graydon S. Staring, The Law of Reinsurance Contracts in California in Relation to AngloAmerican Common Law, 23 U.S.F. L. Rev. 1, 5-6 (1988) (referring to New York Bowery, 17 Wend. at 359; 2 DUER, supra note $77, \S 33$, at $429-30$ ). 
policy. ${ }^{102}$ The substantial differences between original insurance and reinsurance prevent the blind application of the policies of original insurance to reinsurance. An examination of the aspects of original insurance that argue against a inere nondisclosure rule deinonstrates that the policies tlrat support the rule in original insurance do not apply to reinsurance. Rather, the unique aspects of reinsurance deinand a separate and distinct analysis to determine the best rule of disclosure.

The reasons for the original insurance rule's requirement of an intentional or fraudulent concealment were explained by Chief Justice Taft, then a Circuit Judge on the United States Court of Appeals for the Sixtlı Circuit. In Penn Mutual Life Insurance Co. v. Mechanics Savings Bank \& Trust Co. ${ }^{103}$ lie conipared the rule of niere nondisclosure in the case of niarine nisurance to cases of fire and life insurance. ${ }^{104}$ In inarine insurance, the risk is highly speculative, and the insurance coinpany is not afforded the opportunity to investigate the risk. As such, Judge Taft found that "it is manifestly the duty of the imsured to advise the insurer of every circumstance within his knowledge from which the probability of a loss can be inferred, and he cannot be pernitted to escape the obligation by a plea of inadvertence or negligence."105 By contrast, in the case of life and fire insurance, "the parties stand nuch niore nearly on an equality," 106 because the subject of the life or fire insurance can be investigated and examined.107 These differences led Judge Taft to hold that although mere innocent nondisclosure would void a inarine insurance contract, a nondisclosure in a life or fire inisurance contract required intentional concealment or fraud to avoid the policy-innocent nondisclosure would not be sufficient. ${ }^{108}$

Judge Taft was faced witl the argunient that "utinost good faith (uberrima fides) is required in all contracts of insurance, and hence the saine rule of concealment must apply to life and fire insurance [as to marine insurance], and must avoid a policy for nondisclosure of a n1aterial fact, thouglı n1 entire good faitll." 109 Judge Taft rejected this argunient by noting that "the peculiar circumstances under which inarine policies are issued require a construction of their tenns that is not given

102. KEETON \& W1Diss, supra note $82, \S 5.8$, at 573 .

103. 72 F. 413 (6th Cir. 1896).

104. See id. at 434-35.

105. Id. at 434.

106. $I d$.

107. Id. at 434-35. In addition, Judge Taft noted that in the case of life insurance, questions of concealinent often do not arise until after the insured's death. Id. at 435.

108. Id. at 43435 .

109. Id. at 437. 
to policies of life and fire insurance."110 He tlien reasoned that even though the same standard of utmost good faith apphed to marine insurance as to life and fire insurance, the different circumstances could demand different applications when that standard was apphed to life and fire insurance as opposed to marine insurance. ${ }^{111}$

This analysis inay also be apphed to the differences between reinsurance and original imsurance. Like tlie original insurer in marine insurance, the reinsurer does not investigate the risk but rather rehes wholly on the ceding insurer for information. ${ }^{112}$ Moreover, like the original insurer and insured in life and fire insurance, tlie remsurer and its ceding insurer "stand inuch more nearly on an equality,"113 albeit for different reasons. The reinsurer and its ceding imsured are both sophisticated insurance companies familiar with the customs and practices in the industry. It is perfectly reasonable to hold a sophisticated ceding insurer to a high standard of disclosure because it should be in the position to know what facts would be material to the reinsurer.

\section{B. Misrepresentation}

In the case of misrepresentation, the duty of good faith often need not be discussed because a false statement witl knowledge of its falsity by definition would violate any duty of good faith. Courts have considered whether scienter requires an intent to deceive, and have most often concluded that knowledge of falsity is sufficient.

In Calvert Fire Insurance Co. v. Unigard Mutual Insurance Co.,$^{114}$ the court summarized the essential elements of a cause of action for rescission based upon misrepresentations. First, the representations must be made with knowledge of their falsity or made as a positive statement of known fact without knowledge as to their trutli or falsity. ${ }^{115}$ Second, the party seeking rehef must have believed the representations to be true. ${ }^{116}$ Lastly, the party seeking relief inust have rehed and acted upon the misrepresentations to his detriment. ${ }^{117}$ The court held that proof of

110. Id.

111. Id. at $437-38$.

112. It could be argued that the reinsurer could, as an expense of doing business, investigate risks of which it was unsure. The longstanding custom of the industry, however, is that reinsurers do not conduct independent investigations, and many are not equipped to do so. Moreover, this Note is concerned with the legal issues involved, and does not advocate the change of this business practice.

113. Penn Mutual, 72 F. at 434.

114. 526 F. Supp. 623 (D. Neb. 1980), affd, 676 F.2d 707 (8th Cir. 1982).

115. Id. at 633 .

116. Id.

117. Id. (citations omitted). 
scienter was necessary. ${ }^{118}$ But this requirement does not employ scienter in terms of an intent to deceive, but rather in terms of knowledge. It is satisfied by proving that the person who made the representation either knew it was false or made it as a positive statement without knowledge as to its truth or falsity. ${ }^{119}$ The Calvert court apphed these principles to rescind the reinsurance contract at issue because the ceding insurer defendants misrepresented material facts concerming, first, the existence of an "Excess and Special Risks Departinent" overseeing the risks to be remsured when in fact no such departinent existed, and second, the premium volume to the reinsurer plaintiffs at the mception of the contract, both of which the reinsurer relied upon to its detriment. ${ }^{120}$ The court did not inention any role of a duty of good faitl in its decision.

Following Minnesota statutory law, the Eightl Circuit in Security Mutual Casualty Co. v. Affiliated FM Insurance Co. ${ }^{121}$ lield that where misrepresentations were material because they increased the reinsurer's risk of loss, rescission was proper. ${ }^{122}$ Althougli the court lield that the reinsurer did not need to show an intent to deceive, the court expressly based this lolding on the wording of the statute, which provided that misrepresentation by a party seeking insurance will not avoid the liability unless: (1) it is made with intent to deceive and defraud, or (2) the matter misrepresented increases the risk of loss. ${ }^{123}$ The court acknowledged that the ceding insurer owed a duty to use the utınost good faith in cominunicatimg with its reinsurer. ${ }^{124}$ Because the ceding insurer's misrepresentations, among otliers, regarding the insured's loss record and the occupancy of the insured's buildings, mcreased the risk of loss, the Security Mutual court upheld the lower court's ruling exonerating the reinsurer froin liability under the facultative reinsurance contract. ${ }^{125}$

In summary, where information is simply not included, no fault need be proven on the part of the ceding msurer before the reinsurer may rescind the contract in inost jurisdictions. By contrast, where misinformation is given, knowledge of the falsity or a positive statement of fact inade without knowledge of its trutli or falsity inust be proven.

118. Id. at 637 .

119. Id.

120. Id. at $639-46,657$.

121. 471 F.2d 238 (8th Cir. 1972).

122. Id. at 246 .

123. Id. at 243; see MinN. STAT. ANN. $\S 60$ A.08, subd. 9 (West 1986).

124. 471 F.2d at 246 .

125. Id. 


\section{Facultative vs. Treaty Reinsurance}

The duty of disclosure may depend on the kind of reinsurance at issue. ${ }^{126}$ In the case of facultative reinsurance, the duty requires the disclosure of "facts ordinarily known at the time concerning the insurance risk of the property or interest to be reinsured."127 In the negotiation of a new reinsurance treaty, however, most policies to be reinsured thereunder are yet to be issued. As a result, the underwriting information required to be disclosed during treaty negotiations must be in "general and anticipatory terms." 128 The disclosure duty for treaty reinsurance has thus been viewed as a "broader" one with respect to such matters as the "terms of the proposed treaty, its interplay with other reinsurance[] the nature of primary policies to be produced, ... its probable use in the future, [and] past loss experience to which the treaty as a whole is likely to be subject." 129

This difference does not necessarily inean that there is a different kind of duty to disclose. Rather, the same duty to disclose applies in both treaty and facultative reinsurance, but it inust be interpreted in hight of the different circumstances peculiar to the discrete relationships. In the case of treaty reinsurance, the parties possess different levels of knowledge pertaining to the risk, and the reinsurer will not have the choice of declining to accept individual risks that fall within the class of risk covered by the treaty. Accordingly, courts and arbitrators need to recognize that to promote efficiency and to fulfill the same good faith level of duty to disclose, a ccding insurer in a treaty relationship inust be specific in its disclosure to enable the reinsurer to understand the potential nature of the expected risks that will be accepted.

Two courts have held that treaty reinsurance warrants the finding of a fiduciary relationship between the reinsurer and the ceding insurer, although the second case found such a relationship only with regard to the administration of already ceded policies. In American Re-Insurance Co. v. MGIC Investment Corp. ${ }^{130}$ the court held that the ceding insurer breached its fiduciary duty to its reinsurer by failing to disclose material information during the initial negotiations for the reinsurance treaty under which the reinsurer (Am-Re) agreed to reinsure lease guarantee insurance provided by the ceding insurer (MGIC). In finding that "utmost good faith is an element of a fiduciary relationship in which one's

126. See supra text accompanying notes 12-17.

127. Kramer, supra note 21 , at 10 .

128. Id.

129. Id.

130. No. 77 CH 1457 (IIl. Cir. Ct., Cook Cty., Ch. Div. Oct 20, 1987). 
word is deemed to be trustworthy,"131 the court reasoned that the fact that the reinsurance involved was treaty reinsurance inherently required Ain- $R e$ to place its trust in the ceding insurer. The court pointed out that " $[t]$ reaty reinsurance does not permit the reinsurer to pick and choose risks; it must automatically accept all risks in the group written by the [ceding insurer]."132 Due to the very nature of treaty reinsurance, Am-Re had no choice but to "place a great deal of trust in the integrity of the defendants." 133 The need for trust was the basis for finding a fiduciary duty. ${ }^{134}$

The court rejected the ceding insurer's argument that it owed merely a duty of good faith and fair dealing, not a fiduciary duty, to its reinsurer.

The dealings between Am-Re and the [ceding insurer] were not at armslength. Only [the ceding insurer] chose the risks to be reinsured by Am-Re; Am-Re accepted these risks in good faith. . . Am-Re had no power of choice. Control was in the hands of the ceding insurer].... The success or failure of the treaty lay in the acceptance of risks which was essentially the sole responsibility of [the ceding insurer]. This treaty, therefore, could not exist without trust, without the imposition of a fiduciary duty between the parties. The nature of the treaty required Am-Re to place a great deal of trust in the integrity of [the ceding insurer]. ${ }^{135}$

Because it found that the treaty could not function without trust, the court found the ceding insurer, who possessed the controlling information, to be the fiduciary of this trust. The fiduciary relationship imposed a duty of full disclosure which the ceding insurer had breached.

In the second case, Mutuelle Générale Francaise Vie v. Life Assurance $C o .{ }^{136}$ which concerned the administration of already ceded policies, the court declined to follow American Re-Insurance as definitive of Illinois law and did not find a fiduciary duty by the ceding insurer to its reinsurers as to the selection of the policies that were to be reinsured under the treaty. ${ }^{137}$ Because the ceding insurer was compelled under the treaty to cede on a mandatory basis the policies specifically defined in the treaty itself, the court found that the ceding insurer was not in a position of superiority or influence to establish a fiduciary duty. ${ }^{138}$ In the administration of the ceded policies, however, the court held that the ceding

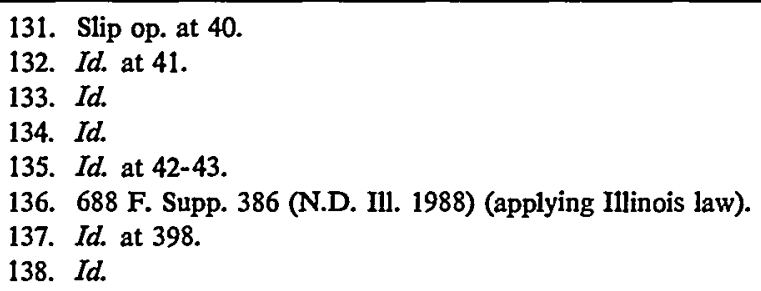


insurer owed a fiduciary duty to the reinsurer because the ceding insurer had sole contact with the policies and pohicyholders for the reinsurer's account. ${ }^{139}$ The ceding insurer was the reinsurer's agent in providing information on the policies, forwarding premiums, and investigating and paying claims. ${ }^{140}$ Thus, where the ceding insurer had either sole discretion or a monopoly of knowledge, the court found a fiduciary relationship.

The court in International Surplus Lines Insurance Co. v. Fireman's Fund Insurance $\mathrm{Co}$. found no such fiduciary duty in a facultative reinsurance pohicy, ${ }^{141}$ rejecting American Re's and Mutuelle Générale's rationales for finding a fiduciary duty in the treaty remsurance context. Noting that "[t]o estabhish the existence of a fiduciary relationship, it must be demonstrated that confidence was reposed in one party to a relationship, resultimg in that party's domination and influence over the other party," 142 the court instead found that "[t]he relationship at issue is governed by a contract negotiated at arms length by two cominercial entities." 143 The court doubted whether one party could dominate the other in the negotiation and performance of the agreement. ${ }^{144}$ The court pointed out that the parties surrounded theinselves with insurance brokers, marketing representatives, and other professionals in the field of insurance. ${ }^{145}$ Most significantly, the court found that "both parties to this relationship are experts in the subject around which their relationship centers." 146 Finally, the court emphasized that "[i]f Illinois courts have not deemed a fiduciary relationship to exist between an individual policy holder and a sophisticated insurance company, they are not likely to imply one in a reinsurance relationship." 147

The court used the last point to expressly disapprove of the Mutuelle Générale holding. ${ }^{148}$ The court stressed the increased retention of control by the cedimg insurer in a reinsurance situation. ${ }^{149}$ The court further

139. Id.

140. Id.

141. No. 88C320, 1989 U.S. Dist. LEXIS 15626, at *5 (N.D. Ill. Dec. 29, 1989). The ceding insurer failed to disclose its reduction in the net retention level as required under the reinsurance contract. Id.

142. Id. at *8-9.

143. Id. at *11.

144. Id.

145. Id. at *11-12.

146. Id. at *12.

147. Id.

148. Id. at *13 ("While it is true that Judge Shadur's decision in Mutuelle Générale recognized the existence of a fiduciary relationship between the reinsurer and its insured, this Court does not believe this is how the Illinois Supreme Court would hold if confronted with the question.").

149. Id. at $* 12$. 
stated that "[i]f the insurer is typically considered the dommant and controlling party, the fact that in a reinsurance relationship the insured has more control cuts against the existence of the extraordinary domination necessary to a fiduciary relationship." 150 The court noted that "other courts have recognized that a reinsurer has a duty to exercise the utmost of good faith in its dealings with its insured."151 Yet the court's rationale for not finding a fiduciary relationship argues against any need for utmost good faith between the parties.

Although this Note does not advocate the finding of a fiduciary relationship in treaty reinsurance, it agrees with the courts above that treaty reinsurance involves special circumstances not found in facultative reinsurance. Because the reinsurer will become bound to accept all risks falling under the treaty, good faith demands specific and full disclosure. Thus a court may find that in specific circumstances good faith demands more complete or detailed disclosure, regardless of the questions or input of the reinsurer.

\section{Recommendation}

As demonstrated above, reinsurance differs from original insurance as to the characteristies of parties involved; types of insurance (indemnity versus hability), including the distinction within reinsurance between facultative and treaty reinsurance; and the burden of investigation of the risk. With regard to disclosure, the most fundainental mistake of courts is to apply the rules of law for original insurance to reinsurance. As explained in Part II(A)(3), the policy reasons given for these rules do not apply to the reinsurance relationship. Accordingly, an independent analysis must be undertaken to determine the appropriate rule for reinsurance, considering the current incentives in the reinsurance market.

Although the reinsurer is dependent on its ceding insurer for disclosure because the information concerning the risk lies with the ceding insurer, the sophistication of the parties allows then to contract for the proper disclosure standard. Courts need not apply the policies developed from the adhesive nature of original insurance to reinsurance to prevent the parties from contracting to their own standard. The parties can bargain for the proper standard, whether it be "mere nondisclosure" or intentional concealment. Where the parties have so contracted, courts

150. Id. The counterargument, however, is that because the knowledge lies with the "insured" (ceding insurer), unlike in the original insurance context, and because the "insurer" (reinsurer) does not have the opportunity to investigate the risk, a fiduciary duty runs from the ceding insurer to the reinsurer.

151. Id. at *9-10 (citation omitted). 
should simply enforce the contract, regardless of the law for original insurance. In this inanner, the parties are substituting the deterrence of an enforceable legal standard in the contract for the deterrence the inarket once provided through long-term profitability, reputation, and repeat transactions.

However, inany reinsurer-ceding insurer contracts have not contracted to such a standard, because the parties have either not adjusted to the changes in the market, the parties have found transaction costs too high, or the contract was drafted before, and the parties did not foresee, the present changes in the inarket. Accordingly, courts should adopt a default standard for parties that have not contracted for one. That standard should be what the parties would have bargained for ex ante. ${ }^{152}$

Although the market incentives that caused the ceding insurer to act in utınost good faith have evaporated, the aspects of the reinsurance relationship that demanded full disclosure for an efficient inarket still exist: The information concerning the risk hes with the ceding insurer, and it is costly for the reinsurer to inomitor the ceding insurer's investigation and disclosure of that risk. Absent an express contractual term to the contrary, courts should therefore adopt the inere nondisclosure standard as an information-forcing default rule to encourage full disclosure of all material information. Requiring proof of intentional concealment (or the absence of intentional concealment if the burden is placed on the ceding insurer) would frustrate full disclosure by allowing a ceding insurer to evade responsibility for inadequate disclosure even when it should have disclosed. Such a rule would not provide adequate incentives for full disclosure. Moreover, because of an insurance company's superior knowledge, it may be held to a higher standard of disclosure than an insured in original insurance.

This rule approximates what the parties would have agreed to $e x$ ante. To illustrate, reinsurance contracts involved in large asbestos clanns were drafted before the changes in the inarket that reduced the mcentives for the ceding insurer to act in utmost good faith. As one court recently noted:

[A]s this hitigation amply demonstrates, custom and practice has chauged significantly since 1974 when the Certificate was issued, primarily due to the overwhelming pressures of asbestos litigation. The relationship between ceding companies and reinsurers has become more arm's leugth than it was in the past, and increased insistence by

152. See generally Ian Ayres \& Robert Gertner, Strategic Contractual Inefficiency and the Optimal Choice of Legal Rules, 101 YALE L.J. 729, 729 (1992) (discussing default standards). 
reinsurers on close coinpliance with contractual ... requirements is a natural concomitant of this separation. ${ }^{153}$

In the past, the parties bargained for and expected full disclosure of the risk, but depended on market forces to ensure full disclosure. Because those market forces have evaporated, to give meaning to the parties intent, courts must adopt information-forcing default rules to encourage the full disclosure the parties envisioned. ${ }^{154}$ The court would thus substitute a legal rule to serve the deterrent effect the parties expected of the market.

In sum, where the contract is clear, courts should enforce the parties' bargain regarding the ceding insurer's duty to disclose. Wherc the contract is ambiguous, courts should adopt a legal rule that encourages full disclosure of all material aspects of the risk. The mere-nondisclosure rule best serves that purpose by penalizing nondisclosure. This rule also mimics the reinsurance market's traditional practice of placing the burden of improper disclosure on the party able to avoid it at the least cost. ${ }^{155}$

\section{Duty to Provide Notice of Claim}

Most reinsurance contracts require that prompt notice be given to the reinsurer of any claim subject to reinsurance. Prompt notice of claims permits the reinsurer "to reserve properly, to adjust preiniums to refiect the loss experience under the reinsurance contract, and to decide whether to exercise the option of becolming associated with the ceding msurer in the handling and disposition of the claim." 156 Courts are divided as to whether timely notice should be a condition precedent to coverage under the reinsurance contract or whether soine eleinent of prejudice to the remsurer must be proved. This determination depends on whether the court atteinpts to understand the differences between original insurance and remsurance, and thus the role and inportance of notice to the reinsurer versus the original insurer. As in the case of disclosure, some courts err by attempting to apply the rules of original insurance to reinsurance contracts without considering the differences between the two. Even when courts have considered these differences, however, the differences have been used both to support and to refute a prejudice requirement.

153. Unigard Sec. Ins. Co. v. North River Ins. Co., 762 F. Supp. 566, 591 (S.D.N.Y. 1991).

154. See Ayres \& Gertner, supra note 152, at 729 (discussing "obligationally incomplete" contracts).

155. See generally Guido Calabresi, The Cost of Accidents 135-38 (1970).

156. OSTRAGER \& NEWMAN, supra note $49, \S 14.02$, at 466 . 
Only a few courts have considered the role of good faith in the late notice context, and fewer courts have characterized the duty as "utmost good faith." This Note advocates that good faith should play a role in determining whether the reinsurance contract has been breached.

This Part first discusses the late notice cases that have been decided without reference to good faith, detailing the disagreement over whether prejudice is required under a reinsurance contract and the conflicting rationales courts have used to reach their results. This Part then discusses the cases that have considered good faith duties, which although agreeing that prejudice is required, disagree over the rationale. Finally, after discussing the factors courts consider and the lack of a coherent jurisprudence that reinsurers and original insurers must face when drafting contracts, this Note proposes a method by which courts should decide late notice reinsurance cases.

\section{A. Late Notice Cases Not Considering Good Faith}

As discussed above, the primary question in late notice cases is whether prejudice to the reinsurer by late notice is required for the reinsurer to avoid the claim. Courts often begin their analysis with the prejudice rule of original insurance in the forum state. Whether the prejudice rule of original insurance is applied to reinsurance depends on whether the court recognizes the differences between reinsurance and original insurance. However, even where courts do consider the differences, this consideration does not always lead to the same results. The policy rationales that led to a prejudice requireinent in original insurance have been found both to support and to undercut a prejudice requireinent in reinsurance. Table 1 captures these divergent views and results. 
TABLE 1

Courts AND PREJUdice

\begin{tabular}{|c|c|c|c|c|}
\hline \multicolumn{5}{|c|}{ COURTS AND PREJUDICE } \\
\hline & & \multicolumn{3}{|c|}{$\begin{array}{l}\text { IS THERE A DISTINCTION BETWEEN NOTICE } \\
\text { PROVISIONS IN REINSURANCE AND ORIGINAL } \\
\text { INSURANCE? }\end{array}$} \\
\hline & & \multirow[t]{2}{*}{ No } & \multicolumn{2}{|c|}{ Yes } \\
\hline & & & $\begin{array}{c}\text { The distinction argues } \\
\text { against a prejudice } \\
\text { requirement }\end{array}$ & $\begin{array}{l}\text { The distinction argues } \\
\text { for a prejudice } \\
\text { requirement }\end{array}$ \\
\hline \multirow{2}{*}{$\begin{array}{l}\text { IS } \\
\text { PREJUDICE } \\
\text { REQUIRED? }\end{array}$} & No & $\begin{array}{r}\text { Highlands } \\
\text { Travelers }^{158} \\
1\end{array}$ & $\begin{array}{l}\text { Gibbs }^{159} \\
\text { Jefferson }\end{array}$ & \\
\hline & Yes & Central $^{161}$ & & $\begin{array}{l}\text { Security Mutual } \\
\text { Associated }^{163} \\
\text { Christiania }^{164} \\
\text { Nutmeg }^{165} \\
\text { Unigard (S.D.N.Y.) }^{166} \\
\text { Umigard (N.Y.) }^{167}\end{array}$ \\
\hline
\end{tabular}

1. Cell 1. Two cases, Highlands Insurance Co. v. Employers' Surplus Lines Insurance Co. ${ }^{168}$ and Travelers Insurance Co. v. Buffalo Reinsurance Co. ${ }^{169}$ illustrate courts' refusal to recognize the differences between reinsurance and original insurance, even though they reached the same result reached in Liberty Mutual Insurance Co. v. Gibbs ${ }^{170}$ and

157. Highlands Ins. Co. v. Employers' Surplus Lines Ins. Co., 497 F. Supp. 169 (E.D. La. 1980).

158. Travelers Ins. Co. v. Buffalo Reins. Co., 735 F. Supp. 492 (S.D.N.Y.), vacated in part on other grounds, 739 F. Supp. 209 (S.D.N.Y. 1990).

159. Liberty Mut. Ins. Co. v. Gibbs, 773 F.2d 15 (1st Cir. 1985).

160. Fortress Re, Inc. v. Jefferson Ins. Co., 465 F. Supp. 333 (E.D.N.C. 1978), affd, 628 F.2d 860 (4th Cir. 1980).

161. Fortress Re, Inc. v. Central Nat'I Ins. Co., 595 F. Supp. 334 (E.D.N.C. 1983), vacated on other grounds, 766 F.2d 163 (4th Cir. 1985).

I62. Security Mut. Casualty Co. v. Century Casualty Co., 531 F.2d 974 (10th Cir.), cert. denied, 429 U.S. 860 (1976).

163. Insurance Co. of Pa. v. Associated Int'I Ins. Co., 922 F.2d 516, 524 (9th Cir. 1990).

164. Christiania Gen. Ins. Corp. v. Great Am. Ins. Co., 745 F. Supp. 150 (S.D.N.Y. 1990).

165. General Ins. Co. of Trieste \& Venice v. Nutmeg Ins. Co., No. 6213/85-001 (N.Y. Sup. Ct. July 24, 1987).

166. Unigard Sec. Ins. Co., Inc. v. North River Ins. Co., 762 F. Supp. 566 (S.D.N.Y. 1991$).$

167. Unigard Sec. Ins. Co., Inc. v. North River Ins. Co., 594 N.E.2d 571 (N.Y. 1992).

168. 497 F. Supp. 169 (E.D. La. 1980).

169. 735 F. Supp. 492 (S.D.N.Y. 1990), vacated in part on other grounds, 739 F. Supp. 209 (S.D.N.Y. 1990).

170. 773 F.2d 15 (1st Cir. 1985). 
Fortress Re, Inc. v. Jefferson Insurance Co. ${ }^{171}$ Botli cases applied the applicable law of original insurance to hold that a slowing of prejudice was not required where notice was late.

In applying eitler Massachusetts or Texas law, the court in Highlands dismissed the ceding insurer's claim to enforce a reinsurance contract where "as a inatter of law" the notice was late. ${ }^{172}$ The court expressly declined to draw a distinction between notice provisions in original insurance contracts and reinsurance contracts.

We find no basis in Texas or Massachusetts law for making this distinction, and further find that such distinction would be strained at best, in that the notice provisions in both contracts serve the saine purpose: to afford a company which inay ultimately be liable on a claim the opportunity to participate in the defense of that claim. ${ }^{173}$

Because the applicable state law did not require prejudice in original insurance, no prejudice was required for recovery under a reinsurance contract.

The court in Travelers found that no basis exists under New York law for distinguishing reinsurance from prinary insurance with respect to notice provisions. ${ }^{174}$ Because in New York no prejudice was required to avoid a contract due to late notice in original insurance, the court held that no prejudice was required in the reinsurance context. The court admitted that reinsurance contracts differ froln primary insurance contracts in that reinsurers rarely defend claims, ${ }^{175}$ and noted that "[a]s is customary, the reinsurance Certificates in the instant action provide that the [ceding] insurer will undertake to investigate and defend all claims under the policy."176 The court, however, placed weight on the fact that the reinsurers expressly reserved the right to associate with the full cooperation of the ceding insurer in the defense of any claim, suit, or proceeding which inay involve the reinsurance Certificates. ${ }^{177}$ It further stated that the fact that reinsurers rarely defend in the same manner as primary insurers is not a meaningful distinction with respect to the interpretation of notice provisions. ${ }^{178}$ It perceived any distinction between notice provisions in an original insurance contract and a reinsurance contract as "strained at best," because "in each instance the prompt notice is

171. 465 F. Supp. 333 (E.D.N.C. 1978), affd, 628 F.2d 860 (4th Cir. 1980).

172. 497 F. Supp. at 172-73. The court thus rejected the ceding insurer's argument "that prompt notice is not a condition precedent to liability on a reinsurance contract unless the contract so expressly states." Id. at 173 n.3.

173. Id. at 173 n.3.

174. 735 F. Supp. at 498.

175. Id. at 499 .

176. Id.

177. $I d$.

178. Id. 
designed to afford an insurance company the opportunity to participate in the defense of a claim on which it may ultimately be liable."179 The court thus found no reason to deprive a remsurer of its right to associate in the defense of claims simply because the reinsured is itself an insur. ance company. ${ }^{180}$ Accordingly, the court held that "[t] meaningful distmction between notice provisions in a contract of [original] insurance and a contract of reinsurance precludes any departure from the well established New York rule governing notice [which makes notice a condition precedent to the reinsurer's liability] in the [original] insurance context."181

\section{Cell 2. In Fortress Re, Inc. v. Central National Insurance} Co. ${ }^{182}$ the court assumed that Great American Insurance Co. v. C.G. Tate Construction Co. ${ }^{183}$ involving an original insurance contract, apphed in the reinsurancc context. ${ }^{184}$ Tate developed a three-part test, including a good faith and a prejudice prong, to determine whether an insured could avoid a claim on the basis of late notice. ${ }^{185}$ The rationale for Tate was based on the adhesion principle from original insurance. That is, the fact that original insurance contracts are often not bargained for and issued by msurers on a "take-it-or-leave-it" basis. 186 The parties do not stand on equal footing as they do in the reinsurance context, and

\section{Id.}

180. $I d$.

181. Id. The court did note that the construction of ambiguous contractual terms as covenants rather than as conditions precedent is desirable because it avoids forfeiture, but declined to do so in the insurance context because of the well established New York rule governing notice. Id.

In holding timely notice to be a condition precedent, the Travelers court expressly refused to follow General Ins. Co. of Trieste \& Venice v. Nutmeg Ins. Co., No. 6213/85-001 (N.Y. Sup. Ct. July 24,1987 ), which held that a notice of loss provision in a remsurance contract is not a condition precedent. Travelers, 735 F. Supp. at 498 n.4. The Travelers court found that the supreme "court's cursory analysis is unpersuasive," and further noted both that the court failed to cite any authority for the proposition and that its holding has not been followed by any subsequent New York court. Id.

182. 595 F. Supp. 334 (E.D.N.C. 1983), vacated on other grounds, 766 F.2d 163 (4th Cir. 1985).

183. 279 S.E.2d 769 (N.C. 1981).

184. Central, 595 F. Supp. at 337-39. The court noted the previous "longstanding North Carolina rule ... that a notice clause in a reinsurance certificate was a condition precedent requiring proper notice within a reasonable time, and any unexplained delay in notifying the reinsured negated liability." Id. at 337 (citing Fortress Re, Inc. v. Jefferson Ins. Co., 465 F. Supp. 333 (E.D.N.C. 1978), aff'd, 628 F.2d 860 (4th Cir. 1980)).

185. Tate, 279 S.E.2d at 776.

186. Id. at 773-74. The Tate court expressly relied on three other jurisdietions which supported this rationale: Cooper v. Government Employees Ins. Co., 237 A.2d 870, 873 (N.J. 1968); Brakeman v. Potomac Ins. Co., 371 A.2d 193, 196 (Pa. 1977); Pickering v. Aunerican Employers Ins. Co., 282 A.2d 584, 593 (R.I. 1971). 
"the only term over which the insured has any say is the ainount of coverage." 187 Because it contained a good faith prong, the test will be discussed more fully in Section B.

On appeal, the Fourth Circuit found that the "district court properly held that the principles explained in Tate $I$ are applicable to a reinsurance contract." 188 However, because general issues of fact existed regarding the ceding insurer's good faitl, the Fourtl Circuit vacated and reinanded the district court's grant of summary judgment. ${ }^{189}$

3. Cell 3. Other courts have recognized the differences between reinsurance and original insurance, but disagree over whether the distimction argues for or against a prejudice requirenent to avoid a claim on the basis of late notice. In Liberty Mutual Insurance Co. v. Gibbs, ${ }^{190}$ the U.S. Court of Appeals for the First Circuit leeld tliat Massachusetts law did not require a showing of prejudice to enable the reinsurer to prevail on a clain of late notice against its ceding insurer. ${ }^{191}$ The court found "the language of the [notice] clause to be unambiguous" and interpreted it "hiterally." 192

The court highlighted the differences between original insurance and reinsurance to find that the pohicy reasons given in support of a prejudice requirement in original insurance did not apply to reinsurance. Although the Massachusetts law controlling original insurance claims seened to require prejudice, ${ }^{193}$ the court found that another provision "expressly provide[d] that "the hazards under [reinsurance] contracts shall be deeined distinct in nature from the hazard insured." "194 The court further noted that the reinsurance contract was a contract of indemnity, unlike original insurance contracts. ${ }^{195}$ Accordingly, the court found that the purpose of the prejudice requirement in original insurance, "to protect lay pohicyholders from the hypertechnical application of notice requirements inserted in forms drafted by [original] insurance

187. Tate, 279 S.E.2d at 774.

188. Fortress Re, Inc. v. Central Nat'l Ins. Co., 766 F.2d 163, 165 (4th Cir. 1985).

189. Id. at 167. The North Carohina Court of Appeals, in Great Am. Ins. Co. v. C.G. Tate Constr. Co., 328 S.E.2d 891, 894-95 (N.C. Ct. App. 1985) (Tate In), qualified the good faith prong of the test, and in light of this further explanation, the Fourth Circuit renanded the case because a genuine issue of fact existed.

190. 773 F.2d 15 (1st Cir. 1985).

191. Id. at 18.

192. Id. The notice provision provided: "It is a condition precedent to any liability under this policy that [the ceding insurer] shall upon knowledge of any loss or losses which may give rise to a claim under this policy advise [reinsurer] thereof as soon as reasonably possible." Id. at 16-17.

193. See MASS. Gen. LAws ANN. ch. 175, § 112 (West Supp. 1984-85).

194. Gibbs, 773 F.2d at 18 (quoting MASS. GEN LAWS ANN. ch. 175, § 2A (West 1972)).

195. Id. 
carriers," did "not extend to a situation . . . involving two experienced insurance underwriters who bargained at arm's length."196 Thus, because the notice was late and no showing of prejudice to the reinsurer was required, the court affirmed the district court's ruling that the reinsurer was not hable to its ceding insurer under the reinsurance contract. 197

Similarly, in Fortress Re, Inc. v. Jefferson Insurance Co. ${ }^{198}$ the court stated that the ceding insurer "should be held to a higher standard of compliance with the notice provision because it is an insurance company which knows firsthand the importance of fulfilling its contractual notice requirements." ${ }^{199}$ The court went on to hold that no prejudice was required to relieve the reinsurer from hability after an unexplained delay of twelve inontlis by the ceding insurer in giving the reinsurer notice of the loss. ${ }^{200}$

4. Cell 4. Courts also find that the differences in the contractual relationship between a reinsurer and its ceding insurer and that of an original insurer and its insured require a showing of prejudice in reinsurance, or in states that already require prejudice in the original insurance context, make the argument for the requirement of prejudice even stronger in the reinsurance context. In Security Mutual Casualty Co. v. Century Casualty Co. ${ }^{201}$ the court held that the notice clause was not a condition precedent to hability, mstead stating that if the reinsurer had shown "pecuniary injury" from the late notice, the reinsurer could lave recovered under the policy. ${ }^{202}$ The Tenth Circuit discussed the different purposes of the notice clause in reinsurance and original insurance:

The purpose of notice and proof of loss clauses in prinary insurance contracts is to afford the insurer an opportunity to form an intelligent estimate of its habilities, to afford it an opportunity to investigate the claim while witnesses and facts are available, and to prevent fraud and imposition upon it. In reinsurance contracts, like the one before us,

196. Id. (citations omitted).

197. Id. at 19.

198. 465 F. Supp. 333 (E.D.N.C. 1978), affd, 628 F.2d 860 (4th Cir. 1980).

199. Id. at 338. Accord Ohio Casualty Ins. Co. v. Rynearson, 507 F.2d 573, 578-79 (7th Cir. 1974) (individual insured with superior knowledge of insurance contracts held to higher standard of care for giving timely notice of loss to liability insurer); Stuyvesant Ins. Co. v. United Pub. Ins. Co., 221 N.E.2d 358, 360 (Ind. App. 1966) ("[C]orporations should be held to a higher standard of reasonable time to give notice of a loss, due to superior knowledge available to sucl corporation."). But see supra notes 182-89 and accompanying text for changes in North Carolina law.

200. Jefferson, $465 \mathrm{~F}$. Supp. at 337-38.

201. 531 F.2d 974 (10th Cir.), cert. denied, 429 U.S. 860 (1976). The case involved treaty reinsurance, and some courts have found this fact dispositive. See, e.g., Jefferson, 465 F. Supp. at 336.

202. 531 F.2d at 978. The court stated that "damages would have been an adequate remedy." Id. This Note does not take a position on whether damages or rescission is the proper remedy. 
the investigation and defense of the claim is [sic] usually left to the primary insurer. Although Security was given the right to associate in the defense of claims, when it so desired, such participation was not so essential as it is for a primary insurer. Century had as much reason as Security to see that the death claims in the Anderson Aviation litigation were properly investigated and defended. Between the two msurers, there was little danger of fraud or imposition. ${ }^{203}$

The court supported its holding with three additional propositions. First, a construction of these clauses as covenants rather than as conditions is desirable because it avoids forfeitures. ${ }^{204}$ Second, the court "emphasize[d] the public pohicy considerations that support[ed the] judgment."205 To protect the imsurance-buying public, the solvency of insurers doing business in a given state is assured by requiring them to maintain certain minimum capital reserves. The court stated that the credit received by ceding insurers for reserves ceded to reinsurers helps "keep inany sinall but highly competitive companies in the insurance busmess."206 To allow this credit, reinsurance must be available when a claim is made. To ensure this result, "the Commissioner of Insurance [must be able] to accurately determine whether the transfer of liability is absolute or conditional, [and thus] the language of the contract must be plam and unequivocal."207

Finally, the court stated that "any ambiguity im a reinsurance contract is to be resolved agamst the reinsurer unless the language is that of the original insurer."208 However, the rationale that supports construing ambiguities against an insurer im the usual insurer-insured context does not exist in the reinsurance relationship. In the former, a sophisticated

203. Id. (citation onitted). The court continued: "Had Security shown any pecuniary injury from Century's failure to give thein notice, we beheve damages would have becn an adequate renedy. Our construction of the contract does not deny the reinsurer the protection it needs, and it does give the reinsured the security and returns for which it paid." Id.

204. Id.

205. Id.

206. Id.

207. Id. The court explained:

To allow an insurer to obtain credit for reserves on a reinsurance contract that contains obscure conditions precedent, and then allow the reinsurer to subsequently deny liability, would substantially impair the function of the Commissioner of Insurance. Moreover, it would substantially increase the danger to the public. An apparently solvent insurer might be plunged into insolvency through its reinsurer's retiance on the nonperformance of an ambiguous condition precedent. If we require any condition that inight result in forfeiture to be clearly stated, it will enable the Commissioner to accurately determine when a credit against reserves for reinsurance should be given. A different holding in this case would undermine the Cominissioner's ability to ascertain the solvency of [this state's] insurance conipanies.

Id.

208. Id. (citing Jnstice v. Stuyvesant Ins. Co., 265 F. Supp. 63, 65 (S.D. W. Va. 1967)); see also Christiania Gen. Ins. Corp. v. Great Am. Ins. Co., No. 91-7912, slip op. 6809 (2d Cir. Sept. 3, 1992). 
entity interacts with a relatively unknowledgable insured and the contract often takes on the characteristics of a contract of adhesion. In the case of reinsurance, however, two sophisticated insurance companies, familiar with the terms and customs of the remsurance industry, negotiate the contract. ${ }^{209}$ The exact nature of a given risk might cause the reinsurer to bargain for a particular clause to protect its interests.

In Insurance Co. of Pennsylvania v. Associated International Insurance Co. ${ }^{210}$ the Nimth Circuit concluded that under California law a reinsurer must prove prejudice to prevail on a claim of late notice. ${ }^{211}$ The Ninth Circuit argued that the differences between original insurance and remsurance made the arguments for a prejudice requirement even stronger than $\mathrm{m}$ original msurance. ${ }^{212}$

The Ninth Circuit did not recoginze a duty of "utmost good faith." The court did find that the ceding insurer had the "obligation, implied by law, to perform its duty under the reinsurance contract 'with care, skill, reasonable expedience and faithfulness." "213 The court also noted that insurance comparies had been held to a higher standard of compliance with notice provisions. ${ }^{214}$

In an analysis doctrinally distinct from its utmost good faith analysis discussed infra in Section B, the court in Unigard Insurance Co. $v$. North River Insurance Co. ${ }^{215}$ rejected the view that the principles of original insurance should apply to remsurance, and held that a demonstration of prejudice by the reinsurer should be required to prevail on a late

209. Robert Shulman, Reinsurance: A Primer For the Practitioner, L.A. LAw., Oct. 1980, at 34, 35.

210. 922 F.2d 516 (9th Cir. 1990).

211. Id. at 524. California law provides that original insurers inust also prove prejudice before recovering on late notice clains. See. Campbell v. Allstate Ins. Co., 384 P.2d 155, 156-57 (Cal. 1963) (en banc).

212. Associated, 922 F.2d at 523. Iu so arguing, the court relied heavily on the Third Circuit's opinion in Trustees of the University of Penusylvania v. Lexington Insurance Co., 815 F.2d 890 (3d Cir. 1987). That case, however, seemed to involve "excess insurance" rather than reinsurance. Excess insurance is simply original insurance for a portion of the risk if it reaches a certain level of loss. Thns, excess iusurers, unlike reinsurers, are directly hable and are in privity with the original insured. Excess iusurance is not a contract of indemnity. Although the excess insurer inay rely on the insurer of the first layer of insurance for an investigation of the clain, the contractual relationships involved are distinctly different from those involved in reinsurance. The Ninth Circuit seentingly failed to recognize these differences. Moreover, the passage it quoted froin Lexington to support the requireinent of prejudice used the term "excess insurance" rather than "reinsurance." Associated, $922 \mathrm{~F} .2 \mathrm{~d}$ at 523 .

213. Associated, 922 F.2d at 523 (quoting Kuitens v. Covell, 231 P.2d 552, 554 (Cal. 1951)).

214. Id.

215. 762 F. Supp. 566 (S.D.N.Y. 1991). 
notice claim. ${ }^{216}$ The district court found that notice clauses served discrete purposes in original insurance and reinsurance. In original insurance, the notice clause allows the original imsurer "to conduct an investigation while the evidence is fresh in order to prevent fraud and [to fulfill] its obligation to defend the msured against the claim."217 In remsurance contracts, notice clauses are designed to: "(a) apprise the remsurer of potential habilities, to enable it to set reserves; (b) enable the reinsurer to associate in the defense and control of specific underlying clains being paid under the policy reinsured; and (c) assist the reinsurer in determining whether and at what price to renew reinsurance coverage."218

After coinparing the needs of original insurers and reinsurers, the court concluded that only original insurers face irreparable harm from untimely notice. ${ }^{219}$ Accordingly, some states, including New York, have held that the needs of original insurers deinand prejudice to be presumed, or not required.220 The court explained that "[i]f the claim is fraudulent, the insurer may be unable to collect evidence of the fraud, and thus may have no basis to avoid paying the claim" by proving prejudice. ${ }^{221}$

The court found that the risks to reinsurers posed by untimely notice, by contrast, are not irreparable.222 With regard to the "inability to post reserves in a timely fashion, the reinsurer will generally have some evidence that it would have posted reserves earlier and soine proof as to how its inability to do so has dainaged it."223 The court also found that "while a reinsurer may have difficulty establishing damages arising from an inability to associate in the resolution of the underlying claim, it is important to note that the right to associate is not a right of control."224

216. Id. at 592-93.

217. Id. at 592; see also id. at 581 .

218. Id. at 581 .

219. Id. at 592 .

220. Id.

221. Id. The court continued:

If the insurer is unable to provide for the defense of the insured, both the insured and the insurer may be damaged by an incautious admission, an ill-advised settlement, or an adverse legal outcome. In either case, the harm to the msurer is difficult to measure and may

Id. even be impossible to prove.

222. Id.

223. Id.

224. Id. at 592-93. The court further noted that "under the 'follow the fortunes' doctrine, the mere fact that a reinsurer might have disagreed with its cedent's handling of the claim does not permit it to avoid liability on the reinsurance agreement." Id. at 593. "Follow the fortunes" is a clause that is often included in remsurance contracts. It states that "the liability of the reinsurer shall follow that of the ceding insurer and, except as otherwise provided in this contract, shall be subject in all respects to the terms and conditions of the original insurance contract except as such may purport to,create a direct obligation of the reinsurer to the original insured or anyone other than 
Finally, concerning the renewal of reinsurance, "the reinsurer can present evidence that given timely notice and based on information which it possessed at that time, it would have increased the price or determined that the reinsurance should be terminated."225 The court added that not only is the harm to the reinsurer more easily established, but that the damages are inore easily quantified.226 Thus, because reinsurers do not face the type of irreparable liarm which threatens original insurers from untimely notice of a claim, the court held that prejudice to a reinsurer froin late notice inust be proven for the reinsurer to recover on a late notice claim. ${ }^{227}$

On appeal in Unigard, the Second Circuit certified to the Court of Appeals for the State of New York the following question: Must a reinsurer prove prejudice before it can successfully invoke the defense of late notice of loss by the ceding insurer?228 The Second Circuit noted the split of authority in interpreting New York law 229 and explained that it

the original insurer." (For an example of such a clause, see id. at 572.) The clause is included so often, and is based so much on the traditions and customs of the reinsurance industry, that some have called it a "principle" which is read into the contract regardless of the actual inclusion of such a clause. 1 GERATHEWOHL, supra note 12 , at 466.

225. Unigard, 762 F. Supp. at 592.

226. Id. at 593. The court gave two examples. If the reinsurer had terminated the contract rather than renewed it, the proper remedy would be rescission of the renewed contract. If the reinsurer was unable to post reserves properly, it would be entitled to collect money damages or be relieved of liability under the contract. Id.

227. Id. The court rejected the reinsurer's argument that because the parties are both sophisticated insurers aware of the bnsiness needs for timeliness, a strict rule of disclosure should apply, such as the "no prejudice" rule. Although the court recognized that the parties involved were unlike those in the original insurer-insured relationship, in which the insured is often unsophisticated and unaware of the requirement of timeliness, the court noted that this concern was outweighed by "the fact that the [original] insurer's need for timely notice is much inore urgent than is the reinsurer's, and that the only protection for the [original] insurer is the strict 'no prejudice' rule." Id. at 593 n.10.

The Unigard court noted that it agreed with another recently decided Soutlern District case, Christiania General Insurance Corp. of New York v. Great American Insurance Co., 745 F. Supp. 150 (S.D.N.Y. 1990). In Christiania, a reinsurer sought a declaratory judgenent that it was not obligated to indemnify the ceding insurer under a facultative reinsurance policy because of late notice by the ceding insurer. Id. at 151-52. Addressing this issue, the court noted that "[t]here is a remarkable absence of case law in New York on the relationship between reinsurers and [ceding insurers]. In particular, it is far from clear how New York courts would apply the law of prompt notice in primary insurance cases to cases involving reinsurance." Id. at 158. The court found, however, that the "policy considerations underlying New York's rule that a primary insurer need not demonstrate prejudice when an insured breaches a notice provision are not present in a reinsurance contract." Id. at 159. Because "[r]einsurers have no duty to defend clains, nor is the potential staleness of a claim as significant a concern to a reinsurer as it is to a primary insurer ... reinsurers must show prejudice from the allegedly late notice in order to avoid liability under a reinsurance contract." Id.

228. Unigard Sec. Ins. Co. v. North River Ins. Co., 949 F.2d 630, 631 (2d Cir. 1991).

229. Compare Unigard, 762 F. Supp. at 566; Christiania, 745 F. Supp. at 150; and General Ins. Co. of Trieste \& Venice v. Nutmeg Ins. Co., No. 6213/85-001 (N.Y. Sup. Ct. July 24, 1987) (holding 
was certifying the question because the "determination of the legal requirements for the assertion of a late-notice claim in the reinsurance context is important to purchasers and sellers of reinsurance issued in New York and to the reinsurance industry," and because "the issue directly implicates New York's interest in the interpretation and enforcement of reinsurance contracts executed within its borders."230

The New York Court of Appeals held that proof of prejudice by the reinsurer due to late notice was required under New York law to assert the defense of noncoinpliance with a reinsurance contract. ${ }^{231}$ The reinsurer, Umigard, argued that it was autoinatically reheved from its obligations under the facultative reinsurance contract because its ceding insured, North River, failed to give prompt notice of an " 'occurrence or accident which appear[ed] likely to involve [the] reinsurance' " as required by the notice clause in the contract. ${ }^{232}$ The court noted that under New York law, "the standard provision in a contract of [original] insurance requiring the insured to give the insurer prompt notice of a potential claim operates as a condition precedent; thus, for failure to give notice, the primary insurer 'need not show prejudice before it can assert the defense of noncompliance." "233 The court held, however, that the rationale for presuming prejudice in the original insurance context did not apply to the different relationship between a reinsurer and its ceding insured.

The court explained that the "no prejudice" rule for original insurers

is a limited exception to two established rules of contract law: (1) that ordinarily one seeking to escape the obligation to perform under a contract must deinonstrate a material breach or prejudice and (2) that a contractual duty ordinarily will not be construed as a condition precedent absent clear language showing that the parties intended to inake it a condition. ${ }^{234}$

The New York courts have rehed upon several bases for the exception: (1) to provide the timely notice needed to investigate claims while witnesses and evidence are still available; (2) to protect against fraud; (3) to

that reinsurer must demonstrate prejudice) with Travelers Ins. Co. v. Buffalo Reins. Co., $735 \mathrm{~F}$. Supp. 492 (S.D.N.Y.), (holding that remsurer need not prove prejudice), vacated in part on other grounds, 739 F. Supp. 209 (S.D.N.Y. 1990).

230. Unigard, 949 F.2d at 632.

231. Unigard Sec. Ins. Co. v. North River Ins. Co., 594 N.E.2d 571 (N.Y. 1992).

232. Id. The clause provided in pertinent part: "Prompt notice shall be given by the company to the Underwriting Managers on behalf of the Reinsurers of any oceurrence or accident which appears likely to involve this reinsurance...." Id. at 572.

233. Id. at 571 (quoting Security Mut. Ins. Co. v. Acker-Fitzsimmons Corp., 295 N.E.2d 76, 78 (N.Y. 1972)).

234. Id. at 573 (citations omitted). 
exercise early control over claims and to promote settlement; and (4) to enable an msurer to properly reserve. ${ }^{235}$ The court found that these reasons did not apply im the remsurance context, and thus, ordinary rules of contract interpretation applied. ${ }^{236}$

The court pointed to the following "significant differences" between original imsurance and reinsurance. First, a reinsurance contract is a contract of indemnity, and "operates solely between the reinsurer and the ceding [imsurer]."237 Second, "[a] reinsurer is not responsible for providing a defense [or] for imvestigating the claim ...."238 Third, settlements are the responsibility of the ceding insured and are binding on the reinsurer. ${ }^{239}$ The court found that these differences inake the "failure to give the required prompt notice ... of substantially less significance for a reinsurer than for a primary insurer."240

In addition, the court found that the reinsurer's and its ceding insurer's imterests with respect to pending claims are "generally identical."241 The court pointed to the "follow the fortunes" clauses found in most reinsurance contracts that leave the reinsurers "little room to dispute the [ceding insurer's] conduct of the case."242 The court noted that both parties benefit from the ceding insurer's efficient investigation, defense, and resolution of a claim. The court contrasted these similar interests with those of an original insurer and its insured, which are often adverse. The court stated that because in the original insurance context there inay be disputes over cooperation, coverage, or claimed collusion on the part of the insured, prompt notice for and quick processing and control of a claim are "vital" to an original insurer. The court found that these considerations are greatly diminished in the reinsurance context. ${ }^{243}$

235. Id.

236. Id. at 573-74. The court expressly recognized that its analysis was limited to "the specific prompt notice provision" contained in the North River remsurance contract. Id. at 574. Accordmgly, the court left open the possibility that remsurers and ceding insurers could draft their notice provisions as conditions precedent if they expressly provide as such. See Christiania Gen. Ins. Corp. v. Great Am. Ins. Co., No. 91-7912, slip op. 6809, 6818 (2d Cir. Sept. 3, 1992) ("For a reinsurer to be relieved from its indemnification obligations because of the reinsured's failure to provide timely notice, absent an express provision in the contract making prompt notice a condition precedent, it must show prejudice resulted from the delay.") (citing Unigard, 594 N.E.2d at 573-74).

237. Unigard, 594 N.E.2d at 574.

238. $I d$.

239. Id. Under the "follow the fortunes" clause of the Unigard reinsurance contract, the reinsurer was expressly bound to pay its portion of the settlement negotiated by the ceding insured. $I d$. at $574 \mathrm{n} .2$.

240. Id. at 574 .

241. Id.

242. Id.

243. Id. at $574-75$. 
Finally, the court rejected Unigard's argunient that its "right to associate" clause ${ }^{244}$ gave it an interest similar to the original insurer's and thus inade it necessary for Unigard to have early notice so that Unigard could investigate the claim and foreclose the possibility of fraud. ${ }^{245}$ Although the court agreed that "there are cases in which the reinsurer's right to associate nnay be impaired by late notice from the reinsured," the court nonetheless held that the "critical distinctions between a primary insurer's right to control the investigation and defense of a claim and a reinsurer's 'right of association' with the ceding companies" prevented such an impairment from warranting a presumption of prejudice. ${ }^{246}$ Thus the court held that the presuniption of prejudice that apphies to late notice disputes between an original insurer and its insured would not apply in the reinsurance context. ${ }^{247}$

\section{B. Courts That Recognize a Duty of Good Faith in the Notice Context}

Several courts have expressly considered the imphications of good faith for late notice. In Fortress Re, Inc. v. Central National Insurance Co. ${ }^{248}$ the district court niade a showing of good faith an express part of a three-prong test. The court, however, only apphed a test developed by the North Carolina Supreine Court for original insurance and did not specifically consider the special circumstances of reinsurance. In Unigard Security Insurance Co. v. North River Insurance Co. ${ }^{249}$ the district court considered "utinost good faith" to be separate froin its prejudice analysis. Finally, in Christiania General Insurance Corp. v. Great American Insurance Co. ${ }^{250}$ the Second Circuit attenıpted to apply the duty of

244. Id. at 575. The right to associate provision, which followed the prompt notice provision in Clause C, stated:

[W] hile the Underwriting Managers or the reinsurers do not undertake to investigate or defend claims or suits, the Underwriting Managers directly, or through [their] representatives and/or counsel, shall nevertheless have the right and be given the opportunity to associate with the Company and its representatives at the Reinsurer's expense in the defense and control of any claim, suit or proceeding which may involve this reinsurance with the full cooperation of the Company.

Id. at 575 n.3.

245. Id. at 575 .

246. The court noted that "reinsurers seldoin have occasion to exercise their right to associate." Id.

247. Id. The court did state, however, that it was not foreclosing a late notice defense to a reinsurer; rather, the reinsurer would simply have to demonstrate how it was prejudiced by the late notice. The court gave no guidance on what would constitute prejudice, other than its already noted statement that a reinsurer's right to associate could be impaired by late notice. The court, however, did not even state if such an impairment would rise to the level of prejudice in a late notice defense.

248. 595 F. Supp. 334 (E.D.N.C. 1983).

249. 762 F. Supp. 566 (S.D.N.Y. 1991).

250. No. 91-7912, slip op. 6809 (2d Cir. Sept. 3, 1992). 
utmost good faith, but had difficulty determining what this duty demanded in the notice context.

In applying North Carolina law, the court in Central adopted a three-part test which included a good faith and a prejudice element. ${ }^{251}$ The so-called Tate test applied by the Central court states:

When faced with a claim that notice was not timely given, the trier of fact must first decide whether the notice was given as soon as practicable. If not, the trier of fact inust decide whether the insured has shown that he acted in good faith, e.g., that he had no actual knowledge that a claim might be filed against him. If the good faith test is inet the burden then shifts to the insurer to show that its ability to investigate and defend was inaterially prejudiced by the delay. ${ }^{252}$

In applying the Tate test, the Central court rejected the ceding insurer's argument that to meet its burden of showing it acted in good faith all it had to prove was absence of motive or specific intent not to notify the reinsurer. ${ }^{253}$ The court admitted that "[s]upport for this position can be found in the [Tate] court's statement that '[a]nyone who knows that he may be at fault or that others have claimed he is at fault and who purposefully and knowingly fails to notify ought not to recover even if no prejudice results." "254 The Central court, however, in holding that "[a] bad motive or specific intent is not required" for a showing of bad faith, ${ }^{255}$ pointed to the Tate court's example of good faith as lack of actual knowledge that a claim had been filed, ${ }^{256}$ and to the explanation that the good faith " "requirement is in accord with the common law principle that implicit in every contract is the obligation of each party to act in good faith." "257 The court held that "where two business entities deal at arms length, unreasonable or unfair dealings can amount to a lack of good faith."258 The court concluded that the "defendant's conduct is so lacking in reasonableness and fair dealing that it amounts to a lack of good faith as a matter of law."259

251. Central, 595 F. Supp. at 338. See generally Carlton A. Shannon, Jr., Note, Application of the Tate Test to Notice Requirements in Reinsurance Contracts, 63 N.C. L. REv. 1240 (1985).

252. Central, 595 F. Supp. at 338 (quoting Great American Ins. Co. v. C.G. Tate Constr. Co., 279 S.E.2d 769, 776 (N.C. 1981)).

253. Id.

254. Id. (quoting Tate, 279 S.E.2d at 776).

255. Id.

256. Because the ceding insurer was aware of the clain for over three years before it gave notice, id., the court must have concluded froin the Tate example that actual notice of a claim followed by a delay in notifying the insurer/reinsurer amounted to a lack of good faith.

257. Id. (quoting Tate, 279 S.E.2d at 776).

258. Id. at 339. It is not clear why this statement would be more true in this context than in an original insurance contract of adhesion.

259. Id. Although the Tate test does not require a finding of prejudice when bad faith is present, the Central court nonetheless found that "[e]ven without a finding of defendant's lack of good faith, the failure to notify plaintiffs until three working days prior to trial resulted in prejudice thereby 
On appeal, the Fourth Circuit vacated the summary judgment for the reinsurer and remanded the case in hight of Tate II. ${ }^{260}$ The Fourth Circuit held that Tate $I I$, though a mere state court of appeals decision, demonstrated that North Carolina law viewed the good faith prong as a subjective, rather than an objective, test. ${ }^{261}$ Thus, based on Tate II, the Fourth Circuit concluded that unreasonable or unfair dealings do not alone constitute bad faith, but rather that "'actual knowledge, and an intentional, i.e., purposeful and knowing, failure to notify" ' is required. 262

The second case to consider good faith, Unigard Insurance Co. $v$. North River Insurance Co. , ${ }^{263}$ expressly recognized that the "relationship between a reinsurer and its ceding insurer, as that between any imsurer and its insured, is characterized by the principles of uberrima fides, or utmost good faith."264 The court interpreted this duty as compelling a distinct analysis of whether "North River [the ceding insurer] violated this duty with respect to Umigard [the remsurer]."265

The court held that the duty of "utinost good faith" could be violated in two ways. First, the court inquired whether the ceding insurer "purposely withheld information."266 Unigard arose froin a coinplex set of facts involving asbestos claims against a host of insurers, and consequently, a potential for contribution froin their reinsurers. In Unigard, North River, the ceding insurer, had signed the Wellington Agreement, which included inany manufacturers of asbestos and their insurers, to

voiding the contract." Id. The court then defined prejudice as "the irretrievable loss of the bargain." Id. Finding that in this case the reinsurer lost the ability to participate in the defense and control of the claim and in its evaluation for settleinent purposes, the court held that the reinsurer was prejudiced because it lad lost the right for which it bargained. Id. But see Travelers Ins. Co. v. Buffalo Reins. Co., 735 F. Supp. 492, 529 (S.D.N.Y.) (finding no prejudice wliere late notice prevented the reinsurer from participating in the handling of the claim because the reinsurer "had no field offices or personnel to conduct investigations or to monitor the work of defense counsel"), vacated on other grounds, 739 F. Supp. 209 (S.D.N.Y. 1990).

260. Fortress Re, Inc. v. Central Nat'l Ins. Co., 766 F.2d 163 (4tlı Cir. 1985) (citing 328 S.E.2d 891 (N.C. Ct. App. 1985)).

261. Id. at 166 .

262. Id. (quoting Tate II, 328 S.E.2d at 894).

The Fourth Circuit also rejected the district court's interpretation of what constituted prejudice to the reinsurer. The court found that the district court's conclusion that the reinsurer was prejudiced because late notice caused it to lose its bargained-for right (in the claims association clause) to participate in the defense and control of the claim, "is tantamount to making tinely notice a condition precedent." Id. The court leld that a genuine issue of material fact existed as to whetlier the reinsurer would have participated if given proper notice and whether that participation would lave resulted in a inore favorable disposition of the claim. Id. at 166-67.

263. 762 F. Supp. 566 (S.D.N.Y. 1991).

264. Id. at 588 .

265. Id.

266. Id. 
create a nonprofit "facility" to administer, evaluate, and settle asbestosrelated bodily injury claims. ${ }^{267}$

The good faith question in Unigard was whether the ceding insurer's failure to consult with its reinsurer prior to signing the Wellington Agreennent violated this duty of utmost good faith. The court determined that Uingard (the reinsurer) failed to prove a motive for North River (the ceding insurer) to have "intentionally concealed its plans."268 Thus, the court did not find a "conscious intent ... to prevent Umigard froin learning the truth."269 The court found only that this failure was due to "madvertence coupled with the coinplexities of the remsurance industry."270

The duty of utmost good faith could have been violated in a second way, according to the court, "if [the ceding insurer] inadvertently failed to disclose inaterial information to its reinsurer."271 As described in Part II, this construction normally applies to the formation of the contract, but because of the unusual facts in this case it was apphied to the signing of the Wellington Agreement. Nonetheless, the court found that "the risk was not materially altered by the Wellington Agreement," and thus no violation of the duty of utmost good faith occurred.272

In Christiania General Insurance Corp. v. Great American Insurance Co., ${ }^{273}$ the Second Circuit, applying New York law, stated that "[t]he relationship between a reinsurer and a [ceding insurer] is one of utmost good faith."274 In Christiania, the remsurer alleged that its ceding insurer "breached its fiduciary duty and/or its duty to deal in utmost good faith by virtue of its conscious decision not to provide notice sooner and in failing to provide accurate information to its reinsurers when it did give notice."275 The court rejected the reinsurer's characterization of the reinsurance relationship as a fiduciary one because reinsurance contracts are negotiated at arm's length by experienced insurance companies. ${ }^{276}$

This fact also posed difficnlties for the court when atternpting to decipher what, if anything, the duty of utmost good faith required that

267. Id. at 575-76.

268. Id. at 588 .

269. Id.

270. $I d$.

271. Id. (citing Hare \& Chase, Inc. v. National Sur. Co., 60 F.2d 909, 912 (2d Cir.), cert. denied, 287 U.S. 662 (1932)).

272. Unigard, $762 \mathrm{~F}$. Supp at 588.

273. No. 91-7912, slip op. 6809 (2d Cir. Sept. 3, 1992).

274. Id. at 6828.

275. Id. at 6833 .

276. Id. 
could not be addressed under traditional principles of contract. 277 The court declined to hold that utmost good faith required that where the cedimg insurer consciously or knowingly provided notice late, the reinsurer would prevail regardless of proof of prejudice. ${ }^{278}$ However, the court did state that "[a]t most, a [ceding imsurer's] failure to provide proinpt notice may entitle the reinsurer to rehef without showing prejudice if the [ceding insurer] acted in bad faith."279 The court, however, concluded that the ceding insurer's actions were not done in bad faith or purposely intended to deprive the reinsurer of earher notice. ${ }^{280}$

With regard to whether the infornnation provided by the ceding insurer deinonstrated a "lack of candor," thereby breaching its duty to act in utinost good faith, the court stated that "this is more usefully analyzed under the rubric of whether defendant satisfied its obligation to provide notice that was sufficient to fulfill the purposes for which remsurers require notice."281 The court concluded that any inaccurate or misleading inforination given to the reinsurer regarding notice "may be remedied under traditional contract principles concerning substantial comphance and material breaches, without the necessity of asking whether any lack of candor' amounted to a breach of a duty independent of the contract ...."282

This extensive discussion of the caselaw in the area of late notice in reinsurance deınonstrates both the ways im which courts disagree on several fundamental factors and that they have not developed a uniform analysis. First, some courts insist on applying the primciples of original insurance to reinsurance despite the important differences between the two. Second, courts disagree whether prejudice is required. In this regard, courts even disagree whether the principles of original insurance that support a prejudice requirement argue for or against a prejudice requirenent in reinsurance. Finally, courts disagree whether good faith should be considered in the late notice context. The next section identifies those factors that courts and arbitrators should consider, and advocates a three-part test to enforce notice obligations under a reinsurance contract where the imtent of the parties is not clear.

277. The court admitted that it was difficult to understand precisely what the reinsurer's challenge was to the ceding insurer's alleged breach of duty to act in utmost good faith. The court noted that if the jury determined the notice was in fact late, "whether its failure was conscious or otherwise," then the contract's prompt notice provision would be violated. Id.

278. Id.

279. Id. at 6834 (citing Fortress Re, Inc. v. Central Nat'l Ins. Co., 766 F.2d 163, 165-66 (4th Cir. 1985)).

280. Id.

281. Id. at 6834-35.

282. Id. at 6835 . 


\section{Recommendation for an Analysis of Late Notice in Reinsurance}

As is evident from the cases, there are several competing factors in the interpretation of a late notice clause im a reinsurance contract: (1) the intent of two sophisticated parties in drafting the contract of reinsurance; (2) the policy rationales for a prejudice requirement; (3) the role, if any, of good faith; and (4) the law apphed to original insurance in the forum state. The fourth factor, as explained above, should have hittle or no role in the interpretation of notice clauses in remsurance contracts because of the substantial differences in the parties to and the purpose of such contracts.

This Note advocates the consideration of the remaining three factors by a court or arbitrator considering a late notice defense to a reinsurance contract. First, the intent of the parties should be controlling. Although this may seem a maxim of contract law, because of the adhesive nature of original insurance contracts, courts have found a prejudice requirement even where the contract called for prompt notice to be a condition precedent to hability. ${ }^{283}$ Reinsurance contracts, however, typically involve two sophisticated parties who are familiar with the custoins and practices of reinsurance. Accordingly, the rationale requiring prejudice, notwithstanding an express notice provision to the contrary, does not apply to a contract of remsurance. The parties are capable of protecting their own interests in the drafting of the contract and their bargain should be protected. This is not to say that traditional contract interpretive principles, such as the preference for covenants rather than conditions, should not apply; indeed, such sophisticated parties (and their attorneys) can be expected to be aware of such principles and to draft their contract accordingly. Rather, the intent of the parties should not be usurped by policies not applicable to the reinsurance relationship.

Absent express contract terns to the contrary, courts should fill in ainbiguous contract terms with rules that encourage prompt notice. As in the case of disclosure of infornation regarding the risk, an efficient market depends on prompt and full information flow from the ceding insurer to the reinsurer. Where the market incentives that once promoted this flow of inforination have broken down, courts inust insert rules that will promote the inarket efficiency the parties intended ex ante.

To formulate such a rule, the test applied in Fortress Re, Inc. v. Central National Insurance Co. ${ }^{284}$ is useful, although its rationale based on the adhesive nature of original insurance is inapposite. This Note also

283. See, e.g., Hanover Ins. Co. v. Carroll, 50 Cal. Rptr. 704, 709 (Ct. App. 1966).

284. 595 F. Supp. 334, 338 (E.D.N.C. 1983). 
advocates a three-part test, altliougli the rationale and application differs froin that used in Central.

First, the reinsurer inust prove that the notice was late under the contract. This question was recently considered on rehearing in Travelers Insurance Co. v. Buffalo Reinsurance Co. ${ }^{285}$ in which the court held that a "proinpt notice" provision ${ }^{286}$ requires that notice be given within a reasonable time under the circuinstances; a finding that clearly allows for varying interpretations. As a result, the ceding insurer "has a right to present extrinsic evidence such as custorn and usage regarding the ineaning of the contested provision. Thus, it is the custom and usage of the remsurance industry which must provide the circumstances by which to evaluate the reasonableness of the timing of Travelers' notice."287 Therefore, to decide whether notice was late under the contract, the court or arbitrator most likely will have to mvestigate the customs of the parties and the reinsurance industry to accurately gauge the expectations and intent of the parties. ${ }^{288}$ The special circumstances of the contract and reinsurance relationship at issue should be considered as well.

Second, if notice is indeed late, the ceding imsurer should bear the burden of proving that it acted in good faitl. Although these are two sophisticated busmess entities dealing at arm's lengtli, the structure of the remsurance relationship necessarily places the inforination regarding the claim with the ceding msurer. The reinsurer is wholly dependent on the ceding insurer for information so that it may act in accordance with the contract and protect its mterests by mvolving itself in the mvestigation under a claims association clause or by simply properly setting its reserves. As explained above, courts should adopt rules that encourage tlie transfer of inforination from the ceding insurer to the reinsurer to promote an efficient remsurance market. The "least cost avoider" primciple states that the entity with the best information at the lowest cost

285. 739 F. Supp. 209 (S.D.N.Y. 1990).

286. See Travelers Ins. Co. v. Buffalo Reins. Co., 735 F. Supp. 492,494 (S.D.N.Y.) (quoting the notice clause at issue), judgment vacated on other grounds, 739 F. Supp. 209 (S.D.N.Y. 1990).

287. Travelers, 739 F. Supp. at 212-13 (citations omitted). The court then found that testimony regarding the length of time which ordinarily lapses before notice is given in the reinsurance industry precluded suininary judgment on whether the ceding insurer's two-and-one-half-inonth delay was late as a matter of law. Id. at 212. Travelers (the ceding insurer) had deposition testimony that "delays are inherent in the remsurance industry because of the manner in which notice is transmitted. ... [I]t is normal custom and usage in the reinsurance industry for notice to pass from a ceding coinpany to a reinsurance intermediary and then through an insurance exchange before finally arriving at the reinsurer's office." Id.; see also Christiania Gen. Ins. Corp. v. Great Am. Ins. Co., No. 91 7912, slip op. 6809, 6817-18 (2d Cir. Sept. 3, 1992).

288. Of course, consistent with protecting the bargain of the parties, where the period of time elapsed that would constitute late notice is express (such as one month from the time the ceding insurer knows that there is a reasonable possibility that its reinsurance may be involved), that express provision will control and extraneous factors will not need to be considered. 
should bear the risk of miscommunication of this information. ${ }^{289}$ In this case, that entity is the ceding insurer.

But what does good faith require in this context? In Central, unlike Unigard, good faith in the context of late notice did not require a bad motive or specific intent, but rather "depend[ed] on the context."290 The court held that "where two business entities deal at arms length, unreasonable or unfair dealings can aniount to a lack of good faith."291 The court also stated, as did the court in Unigard, that nere negligence did not amount to a lack of good faith. ${ }^{292}$

On appeal ni Central, the Fourth Circuit found that North Carolina courts had rejected "unreasonable dealings" standard of good faith in favor of a "subjective intent" standard. ${ }^{293}$ Nonetheless, requiring an intent to deceive is not a workable or desirable standard of good faith in the reinsurance context. The circunstances of the reinsurance relationship, as described above, deinand that the reinsurer depend on its ceding insurer for rehable information, and such a standard of good faith would not meet the needs of the parties. Further, because the knowledge hes with the ceding insurer, the burden of proving intent to deceive would be difficult to discharge if imposed on the reinsurer, or could invite fraud if the burden rested with the ceding nisurer.

Nor should nere neghigence violate the duty of good faith. As the Travelers court noted, a ceding insurer, uulike an insured in the original insurance context, inay depend on a chain of events or people to notify the reinsurer. ${ }^{294}$

The proper standard in niost cases should be gross negligence or recklessness. If a party to a reinsurance contract does not inipleinent controls to ensure notification of its reinsurer in the event of a claini that may reasonably involve the reinsurance contract, this should constitute an "unreasonable dealing" and thus bad faith under the contract. ${ }^{295}$ A reinsurer, dependent on its ceding insurer for information, should be able to expect at least this level of good faith. If this standard of good faith is not niet, the reinsurer inay avoid the claim.

289. See generally CALABRES1, supra note 155 , at 135-38.

290. Fortress Re, Inc. v. Central Nat'1 Ins. Co., 595 F. Supp. 334, 338 (E.D.N.C. 1983). The court continued that "good faith unay mean 'an honest intention to abstain from taking any unconscientious advantage of another ... together with the absence of all information, notice, or benefit or belief of facts which could render a transaction unconscientious.' " Id. at 338-39 (quoting Jaudon v. Swink, 276 S.E.2d 511, 513 (N.C. App. 1981)).

291. Id. at 339.

292. See id.; Unigard Ins. Co. v. North River Ins. Co., 762 F. Supp. 566, 588 (S.D.N.Y. 1991).

293. See Fortress Re, Inc. v. Central Nat'1 Ins. Co., 766 F.2d 163 (4th Cir. 1985).

294. See Travelers Ins. Co. v. Buffalo Reins. Co., 739 F. Supp. 209, 212-13 (S.D.N.Y. 1990).

295. See Central, 595 F. Supp. at 339. 
Finally, if the ceding insurer can prove that it acted in good faith, the reinsurer should then bear the burden of proving that it has been prejudiced by the late notice. Requiring the ceding insurer to prove it acted in good faith provides adequate incentive for it to promptly transfer information, in this case notice of a claim, to the reinsurer. Because the ceding insurer must first prove good faith or be unable to recover under the contract, subsequently requiring the reinsurer to prove it was prejudiced to avoid the claim should not affect the incentive of the ceding insurer to notify its reinsurer promptly. Under this proposed test, the reinsurer has received the good faith it had a right to expect froin its ceding insurer, and thus the policy reasons of certainty and preventing unpaid claims supporting a showing of prejudice prevail.

\section{CONCLUSION}

The primary mistake of most courts considering reinsurance issues is blindly applying primciples of original insurance. Before applying a rule of original insurance to reinsurance, a court or arbitrator inust consider the circumstances of reinsurance that differentiate it from original insurance: Two sophisticated business entities familiar with the custoins and practices of insurance and reinsurance negotiate a contract of indernmity that necessarily places the information regarding the risks to be ceded in the hands of the ceding insured. Only after these circumstances are considered can a coherent result be reached regarding the duties required by good faith under the contract.

Although the parties can, and inay, specifically contract in these areas for the expected conduct, historically, parties to a reinsurance contract have reled on an implied duty of "utinost good faith." Recently, the reinsurance inarket has changed due to the enormous environinental clamis and the decline of profitability resulting in inore contentious relationships. These factors deinonstrate that characterizing the reinsurance relationship as one of utınost good faith is no longer an accurate description. Formerly, differences had been settled by handshakes so as not to poison a profitable long-term business relationship. Today, differences are inore often resolved before courts and arbitrators. The sparseness of caselaw and precedent have placed courts in the unenviable position of developing a coherent jurisprudence.

Courts should enforce the bargains of these sophisticated and experienced parties. Absent express terms, however, courts should adopt information-forcing default rules: the inere nondisclosure rule for initial disclosure of the risk and the good faith/prejudice rule for notice of a clain. 